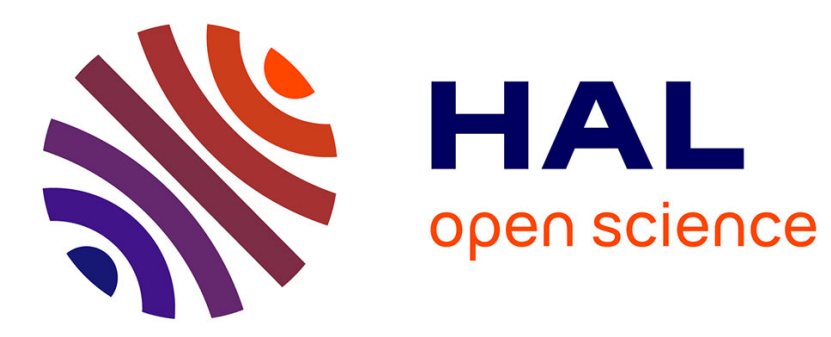

\title{
Detecting unsustainable pressures exerted on biodiversity by a company. Application to the food portfolio of a retailer
}

\author{
Anastasia Wolff, Natacha Gondran, Christian Brodhag
}

\section{To cite this version:}

Anastasia Wolff, Natacha Gondran, Christian Brodhag. Detecting unsustainable pressures exerted on biodiversity by a company. Application to the food portfolio of a retailer. Journal of Cleaner Production, 2017, 166, pp.784-797. 10.1016/j.jclepro.2017.08.057 . emse-01575571

HAL Id: emse-01575571

https://hal-emse.ccsd.cnrs.fr/emse-01575571

Submitted on 21 Aug 2017

HAL is a multi-disciplinary open access archive for the deposit and dissemination of scientific research documents, whether they are published or not. The documents may come from teaching and research institutions in France or abroad, or from public or private research centers.
L'archive ouverte pluridisciplinaire HAL, est destinée au dépôt et à la diffusion de documents scientifiques de niveau recherche, publiés ou non, émanant des établissements d'enseignement et de recherche français ou étrangers, des laboratoires publics ou privés. 
Detecting unsustainable pressures exerted on biodiversity by a company. Application to the food portfolio of a retailer

Anastasia Wolff $^{(a, b)}$, Natacha Gondran ${ }^{(b)}$, Christian Brodhag ${ }^{(b)}$

Affiliations:

(a) AgroParisTech, F-75005, Paris, France;

(b) Univ Lyon,- Ecole Nationale Supérieure des Mines de Saint Etienne, CNRS, UMR 5600 EVS, F-42023

Corresponding author: Anastasia Wolff, anastasia.wolff@ agroparistech.fr

\section{Accepted for publication in Journal of Cleaner Production}

Recommended citation: Wolff, A.; Gondran, N. \& Brodhag, C. (accepted). Detecting unsustainable pressures exerted on biodiversity by a company. Application to the food portfolio of a retailer. Journal of Cleaner Production. DOI: 10.1016/j.jclepro.2017.08.057

\section{Summary}

Companies are called by institutional organizations to assess their impacts on biodiversity and to take actions to achieve collectively conservation objectives. This paper presents a method to assess whether the pressures exerted by a business and its value chain on biodiversity are compatible with biodiversity conservation. The absolute environmental sustainability assessment framework is used to compare relevant life cycle assessment midpoint and endpoint indicators to the ecological budgets assigned to the company. This approach is illustrated based on the case study of a mass-market retailer with a focus on the pressures exerted by its food portfolio at the agricultural production step. The results indicate that several pressures driving biodiversity loss are not sustainable. The study also highlights the prominent weight of a few product categories in the ecological burden. These findings have implications for mass-market retailers as well as their food value chains and open research perspectives to make such an approach fully operational.

Key words: sustainability; biodiversity; business; carrying capacity; life cycle assessment; corporate social responsibility 


\section{Highlights}

- Development of policies to broaden business engagement in biodiversity conservation on a voluntary basis.

- Content analysis of private and public companies' commitments endorsed as contributions to the French NBSAP.

- Substantive practices, which follow the mitigation hierarchy completed with care activities, address differentially the drivers of biodiversity loss.

- Stakeholders from the territory, the value chain and the institutional system play important roles in the implementation of CSR practices.

- Recommendations to fully exploit CSR potential, broaden the application of the mitigation hierarchy and develop business engagement into NBSAPs. 


\section{Introduction}

We are experiencing critical loss of biodiversity driven by anthropic pressures. Despite a wide political recognition of this ecological crisis and the importance to tackle it to safeguard ecosystem services, previous efforts have been insufficient to reverse the trend (Butchart et al., 2010; Tittensor et al., 2014). The Strategic Plan for Biodiversity 2011-2020, adopted at the $10^{\text {th }}$ Conference of the parties of the Convention for Biological Diversity (CBD) sets the international agenda for biodiversity conservation (Nagoya, October 2010) which calls for concerted and effective action. It clarifies expectations regarding business engagement (Decision X/21). The private sector is notably encouraged to contribute to the achievement of these targets and to assess its impacts on biodiversity (COP10 CBD, 2010).

Assessing the impacts of a company on biodiversity and whether these impacts are compatible with the objective of biodiversity conservation is not straightforward. First, biodiversity dynamics cannot be summarized by a single indicator. Furthermore, establishing the causal links between business activities and biodiversity loss can be challenging: a company exerts ecological pressures beyond its own land and premises, at multiple stages of its value chain through its operations, supply chains and the products and services it delivers. The integrative character of biodiversity loss, driven by multiple local (e.g. habitat loss) and global (e.g. climate change) pressures resulting from cumulating human activities, hampers the attribution of biodiversity loss to an individual entity. In addition to this liability issue, assessing whether the ecological pressures exerted by a company are compatible with conservation objectives requires to understand which levels of pressures ecosystems are able to undergo without being significantly affected.

The concept of carrying capacity, defined as "the maximum sustained environmental interference a natural system can withstand without experiencing native changes in structure or functioning that are difficult or impossible to revert" (Bjørn, 2015), has been recently used to develop "absolute environmental sustainability assessment" (AESA) methods (Bjørn and Hauschild, 2015; Doka, 2016; Sandin et al., 2015). The general principle of AESA is to compare the environmental footprint of an entity with its assigned share of carrying capacity (its environmental budget). If its footprint exceeds its budget, then the environmental impact of the entity is qualified as unsustainable. AESA offers promising perspectives but also scientific and technical challenges to assess whether business activities are compatible with biodiversity conservation objectives.

The objective of this contribution is to propose and experiment an adaptation of the AESA approach to the biodiversity impacts of an organization and its value chain. The method is applied to assess the ecological sustainability of the food portfolio of a mass-market retailer. The case study is based on a research project in partnership with Groupe Casino, a french retailer company. This case study served as a test of the relevance of the results to support strategic decision-making.

Section 2 presents the AESA framework and its possible applications to consider whether the ecological impacts of a company are compatible with biodiversity conservation objectives. Section 3 describes the case study as well as the methods used to assess the ecological burdens and the ecological budgets of the entity. The results are then presented and discussed in Section 4. Finally, the main conclusions are reported in Section 5. 


\section{State of the art}

The objective of this study was to tailor the AESA framework to assess whether the pressures exerted by a company are compatible with biodiversity conservation. To do so, consistent methods for modeling the environmental footprint and the environmental budget of the company need to be defined (Figure 1). This section presents the theoretical background for:

(i) defining a scope of study consistent with the extent of corporate social responsibility,

(ii) modeling the business impacts on biodiversity,

(iii) assigning ecosystems' carrying capacities to business.

Figure 1 - Representation of the AESA approach.

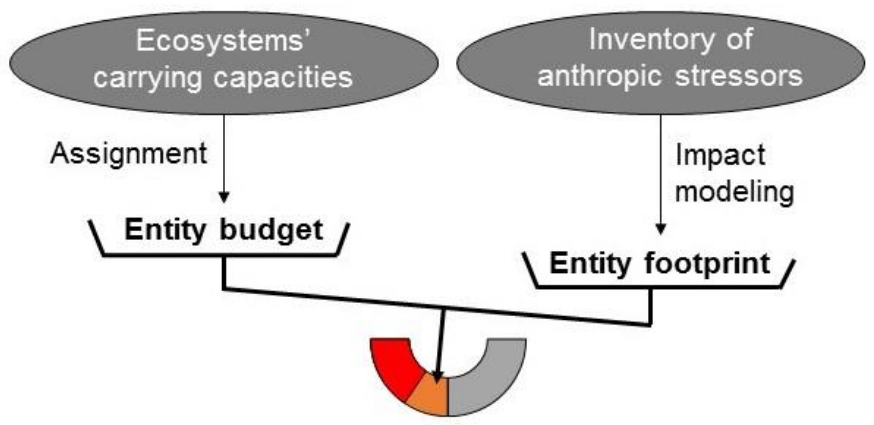

\subsection{Scope definition: business responsibility regarding the footprint of its value chain}

Endeavoring to assess the pressures exerted on biodiversity by a company with an absolute sustainability perspective, arises the question of the scope of the assessment.

A company exerts both direct and indirect environmental pressures. Direct environmental pressures can be defined as consumptions or emissions generated by the company on its industrial or commercial site, such as wastewater or atmospheric emissions, for example. These environmental impacts are in many countries directly under the company's legal responsibility. The question of indirect pressures that are accumulated along value chains is more difficult to regulate within a legal framework. They can be however at least as important to tackle: for several developed countries, more threats on biodiversity are exerted abroad than at home, due to the consumption of imported goods (Lenzen et al., 2012). Corporate social responsibility (CSR) is defined as "the responsibility of enterprises for their impacts on society" (European Commission, 2011). Business decisions have consequences downstream (e.g. sourcing strategy, purchase choices, subcontracting, investment choices, material or ingredient composition of products) and upstream (e.g. energy consumption of their products, waste generation). From a CSR perspective, pressures exerted upstream and downstream are to be accounted for because they lay within the sphere of influence of a company (ISO 26000 ), even if they are more difficult to assess and manage than direct emissions and consumptions. The downstream responsibility of companies is already partially recognized by the European regulation with the "extended producer responsibility" (European Parliament and European Council, 2008) that attributes to the producer the responsibility to prevent, recover, re-use and recycle the wastes that are generated by the products that are brought to the marketplace. On the upstream side, « consumption-based accounting », which allocates all emissions occurring along the chains of production and distribution to the final consumers, assumes that "goods and services will not be produced, bought, sold and traded across borders, unless there is a demand for them" 
(Rothman, 1998). It aims at raising awareness among the various actors of a given supply chain (companies, final consumers, local authorities) to get aware about the global environmental pressures that are linked to their consumption.

Thus, the functional unit of the AESA of a company should ideally cover its entire products and services portfolio provided over one year from cradle to grave. Assessing the impacts on biodiversity of the whole value chain of a company would require large and geographically resolved datasets. Despite important efforts so far to increase data quality and coverage, such an extensive approach is currently not practicable (Clift et al., 2017). In this perspective to support business decision making, a more pragmatic approach can be to focus on the most critical stages of the value chain when previous studies enable to identify hotspots, which is the option chosen for the present case study. It should be stressed that the scope and the functional unit of analysis have to be defined in a consistent way while assessing business impacts and assigning carrying capacities in order to make the comparison meaningful.

\subsection{Models for assessing business impacts on biodiversity}

Five types of processes are responsible for biodiversity loss: habitat change, overexploitation of wild populations, invasive species, pollutions and climate change (Millennium Ecosystem Assessment, 2005; SCBD, 2010). Several approaches have been developed to assess the impacts of human activities on biodiversity. Depending of methods, different components and attributes of biodiversity are considered (e.g. species richness, ecosystems' functions) and impacts are modeled by accounting for one or more anthropogenic pressures. Four integrative causal models have already been applied to assess multiple human-induced pressures on biodiversity:

- GLOBIO (Alkemade et al., 2009),

- biodiversity footprint based on multi-region input-output (MRIO), with some variants: (a) rare species threats analysis (Lenzen et al., 2012; Moran et al., 2016; Moran and Kanemoto, 2017), (b) species range and displacement analysis (Kitzes et al., 2016) and (c) risk of species extinction analysis (Sandström et al., 2017).

- ecological footprint (Borucke et al., 2013),

- life cycle assessment (LCA) where damage to ecosystem diversity is considered as an area of concern (Curran et al., 2010; Goedkoop et al., 2013).

Some authors have recently proposed combinations of these models, for instance combination of MRIO-based biodiversity footprint with GLOBIO (Wilting et al., 2017; Wilting and van Oorschot, 2017) and combination of MRIO models with LCA (Verones et al., 2017).

These four models were reviewed to select the most appropriate approach to assess the impacts of a company and its value chain on biodiversity. Table 1 gives an overview of the different components accounted for in these four models (developed in different fields of study). To compare them, the following terminology was used : "stressors" refer to emissions and consumptions, "anthropic pressures" encompass the five types of processes responsible for biodiversity degradation (habitat loss, climate change, overexploitation, invasive species, pollutions), "biodiversity state" stands for the composition, structure and function of biodiversity at the ecosystem, species and genetic scale, and "impacts" relate to biodiversity loss (trend) as well as benefits from biodiversity and ecosystem services. 
Table 1 - Comparison of the aspects taken into account by models assessing the impacts of human activities on biodiversity.

\begin{tabular}{|c|c|c|c|c|c|c|}
\hline Models & $\begin{array}{l}\text { Entity under } \\
\text { study }\end{array}$ & $\begin{array}{l}\text { Modeled } \\
\text { area; } \\
\text { resolution }\end{array}$ & Stressors & Anthropic pressures & Biodiversity state & Impacts \\
\hline GLOBIO & Territory & $\begin{array}{l}\text { World; eco- } \\
\text { regions; } \\
\text { spatial } \\
\text { resolution of } \\
0.5^{\circ} \text { by } 0.5^{\circ}\end{array}$ & $\begin{array}{l}\text { Multiple, for a large part } \\
\text { modeled by Integrated } \\
\text { Model to Assess the } \\
\text { Global Environment } \\
\text { (IMAGE; MNP 2006) }\end{array}$ & $\begin{array}{l}\text { Land use, atmospheric nitrogen } \\
\text { deposition, infrastructure, } \\
\text { fragmentation, climate change }\end{array}$ & $\begin{array}{l}\text { Terrestrial, freshwater and } \\
\text { marine species abundance } \\
\text { (independent models) }\end{array}$ & $\begin{array}{l}\text { Mean abundance of original } \\
\text { species } \\
\text { relative to their abundance in } \\
\text { undisturbed } \\
\text { ecosystems (MSA) and } \\
\text { Ecosystem extent }\end{array}$ \\
\hline $\begin{array}{l}\text { MRIO-based } \\
\text { biodiversity } \\
\text { footprint } \\
\text { (a) }\end{array}$ & Trade flows & $\begin{array}{l}\text { World; } \\
\text { countries }\end{array}$ & Not assessed & $\begin{array}{l}\text { Anthropogenic threat causes } \\
\text { listed by the IUCN Red list } \\
\text { classification scheme excluding } \\
\text { invasive species }\end{array}$ & $\begin{array}{l}\text { Extent of occurrence of } \\
\text { animalia species classified } \\
\text { as endangered, critically } \\
\text { endangered and vulnerable } \\
\text { by the IUCN Red list }\end{array}$ & Number of species threats \\
\hline (b) & Trade flows & $\begin{array}{l}\text { World; } \\
\text { countries }\end{array}$ & $\begin{array}{l}\text { Human appropriation of } \\
\text { net primary productivity } \\
\text { (HANPP) due to } \\
\text { cropland, pasture, } \\
\text { forestry and built-up land }\end{array}$ & $\begin{array}{l}\text { HANPP, interpreted as a } \\
\text { dimensionless intensity factor of } \\
\text { land use }\end{array}$ & $\begin{array}{l}\text { Distribution of terrestrial } \\
\text { breeding bird species and } \\
\text { modeled baseline bird } \\
\text { density }\end{array}$ & $\begin{array}{l}\text { Occupied bird ranges and } \\
\text { missing individual birds }\end{array}$ \\
\hline (c) & $\begin{array}{l}\text { Crop trade } \\
\text { flows }\end{array}$ & $\begin{array}{l}\text { World; } \\
\text { countries }\end{array}$ & $\begin{array}{l}\text { Crop production area, } \\
\text { fresh water used for } \\
\text { irrigation }\end{array}$ & $\begin{array}{l}\text { Land use and blue water } \\
\text { consumption }\end{array}$ & $\begin{array}{l}\text { Accounted for in spatially } \\
\text { explicit characterization } \\
\text { factors }\end{array}$ & $\begin{array}{l}\text { Global potentially disappeared } \\
\text { fraction of species over time }\end{array}$ \\
\hline $\begin{array}{l}\text { Ecological } \\
\text { Footprint }\end{array}$ & Nation & $\begin{array}{l}\text { World; } \\
\text { countries }\end{array}$ & $\begin{array}{l}\text { Demand on biosphere's } \\
\text { regenerative resources } \\
\text { related to provision of } \\
\text { biological resources, } \\
\text { housing, infrastructure, } \\
\text { and absorption of } \mathrm{CO}_{2}\end{array}$ & $\begin{array}{l}\text { Exploitation of biological } \\
\text { resources (plant-based food, } \\
\text { fiber products, livestock and } \\
\text { fish, timber and other forest } \\
\text { products), land cover (space for } \\
\text { artificial infrastructure), climate } \\
\text { change }\left(\mathrm{CO}_{2} \text { emissions) }\right.\end{array}$ & $\begin{array}{l}\text { Biocapacity is a measure of } \\
\text { the amount of biologically } \\
\text { productive land and sea area } \\
\text { available to provide the } \\
\text { ecosystem services that } \\
\text { humanity consumes }\end{array}$ & $\begin{array}{l}\text { Ecological footprint versus } \\
\text { biocapacity, expressed in global } \\
\text { hectare, which is an hectare with } \\
\text { a world-average bioproductivity }\end{array}$ \\
\hline LCA & $\begin{array}{l}\text { Flexible, } \\
\text { based on the } \\
\text { functional } \\
\text { unit } \\
\text { definition }\end{array}$ & $\begin{array}{l}\text { Global; } \\
\text { generally not } \\
\text { localized }\end{array}$ & $\begin{array}{l}\text { Life-cycle inventory } \\
\text { (LCI) of emissions and } \\
\text { consumption of resources }\end{array}$ & $\begin{array}{l}\text { Midpoint impacts: } \\
\text { climate change, acidification, } \\
\text { marine eutrophication } \\
\text { freshwater ecotoxicity, land } \\
\text { use... }\end{array}$ & $\begin{array}{l}\text { Generally not explicit, can } \\
\text { be accounted for in } \\
\text { characterization factors } \\
\text { (exposure and fate factors) }\end{array}$ & $\begin{array}{l}\text { Endpoint indicator: damage to } \\
\text { ecosystem diversity expressed } \\
\text { as the Potentially Disappeared } \\
\text { Fraction of species (PDF) } \\
\text { integrated over area (or volume) } \\
\text { and time, or as loss of species } \\
\text { during a year }\end{array}$ \\
\hline
\end{tabular}


Among the four models, ecological footprint is the less directly related to biodiversity loss. Although this widely used metric can be useful to analyze the "underlying drivers of habitat impacts and biodiversity loss" (Galli et al., 2014; Lazarus et al., 2015), the link between global hectares and biodiversity is not explicit. GLOBIO has been used to model sectoral impacts on biodiversity under different scenarios (Kok et al., 2014). However, it is not suited for assessing the ecological impacts of a company and its value chain. The MRIO-based biodiversity footprint is an effective approach to assess potential biodiversity degradation related to trade as it links consumption and supply chain impacts. It has not been yet applied to an individual company, which would probably requires some developments, and implies that the company has an extended traceability of its global supply chains at a national resolution. Finally, LCA is a common method defined as a "compilation and evaluation of the inputs, outputs and the potential environmental impacts of a product system throughout its life cycle" (ISO, 2006). Two levels of indicators are distinguished in LCA outputs: midpoint indicators that correspond to anthropic pressures and endpoint indicators that include a damage to biodiversity impact indicator.

Although LCA characterization models of biodiversity impacts still need refinements (Curran et al., 2016, 2010), this approach was found to be the most relevant for the purpose of our study. Relevant LCA indicators at midpoint and endpoint levels were used for the absolute environmental sustainability assessment (LCA-AESA) of the business value chain.

\subsection{Setting the limits based on ecosystems' carrying capacities}

The Planetary Boundaries (PB) framework launched by Rockström et al. (2009) explicitly identifies at a global scale capacity thresholds for biophysical processes that define a 'safe operating space for humanity', i.e. that would maintain the Earth in Holocene-like conditions. This framework opens up ways to theorize and operationalize an 'absolute environmental sustainability" approach which uses carrying capacity as a reference to compare environmental impacts to what could be sustainable (Bjørn, 2015; Fang et al., 2015).

Translating this global framework into a system of metrics for strategic business planning involves two steps:

- First, set sustainability limits (define "the size of the cake"),

- Second, chose principles of assignment of carrying capacity between competitive uses (decide "how to cut the cake").

\subsubsection{Ecological boundaries for biodiversity}

Defining carrying capacities consistent with biodiversity conservation objectives is challenging. Some attempts have been made to define biodiversity boundaries at a planetary scale. As part of the PB framework, Rockström et al. (2009) proposed a boundary for biodiversity loss based on an extinction rate of 10 species per million species per year (E/MSY). The rate of biodiversity loss was identified as one of the three earth-system processes, with climate change and interference with the nitrogen cycle, for which the planetary boundaries have already been transgressed, with an actual rate of about 100 E/MSY. The biodiversity section was subsequently renamed "biodiversity integrity" and divided in two items by (Steffen et al., 2015): genetic diversity and functional diversity. They proposed as interim control variables global extinction rate and the Biodiversity Intactness Index (BII). Further work is needed to improve data quality and define biome-specific boundaries at a refined scale (Clift et 
al., 2017). Other theoretical boundaries correspond to the three levels of biological diversity: "the genetic library of life" - reflecting the link between phylogenetic diversity and ecosystem resilience on the long-term, "levels of functional diversity" - accounting for biological functional diversity underlying ecosystem services, and "biome integrity" - translating how different drivers affect biomes states at a global scale (Mace et al., 2014). There is currently no scientific consensus on operational planetary boundaries specific to biodiversity.

Considerable research efforts are needed to determine science-based thresholds for biodiversity. These challenges should not downplay the importance of institutional processes in the definition of these limits. CBD and the United Nations provide international frameworks and targets for biodiversity conservation relevant for business actors. The current Strategic plan for biodiversity set as a common objective "to halt the loss of biodiversity in order to ensure that by 2020 ecosystems are resilient and continue to provide essential services, thereby securing the planet's variety of life" (CBD COP 10, Decision X/2). Taking this normative objective as a reference, the question is not which amount of biodiversity could be loss before experiencing a system shift, but rather what are the conditions to halt biodiversity loss? Biodiversity has multiple interactions with other earth-system processes (Figure 2). Crossing boundaries for some of these processes is likely to decrease ecosystem resilience to other pressures with subsequent feedbacks and cascade effects (Barnosky et al., 2012; Folke et al., 2004), and thus to hamper the achievement of biodiversity conservation targets . Keeping individual anthropic pressures below ecosystems carrying capacities can thus be considered as necessary, although not sufficient, conditions to achieve the objective of halting biodiversity erosion. As suggested by (Wolff et al., 2016a), the ecological limits of the individual processes driving biodiversity loss can be used as operational proxies to define a space potentially compatible with biodiversity conservation.

Figure 2 -Interactions of the biodiversity boundary with other environmental boundaries. The width of the arrows indicates the strength of the potential feedbacks (from (Mace et al., 2014))).

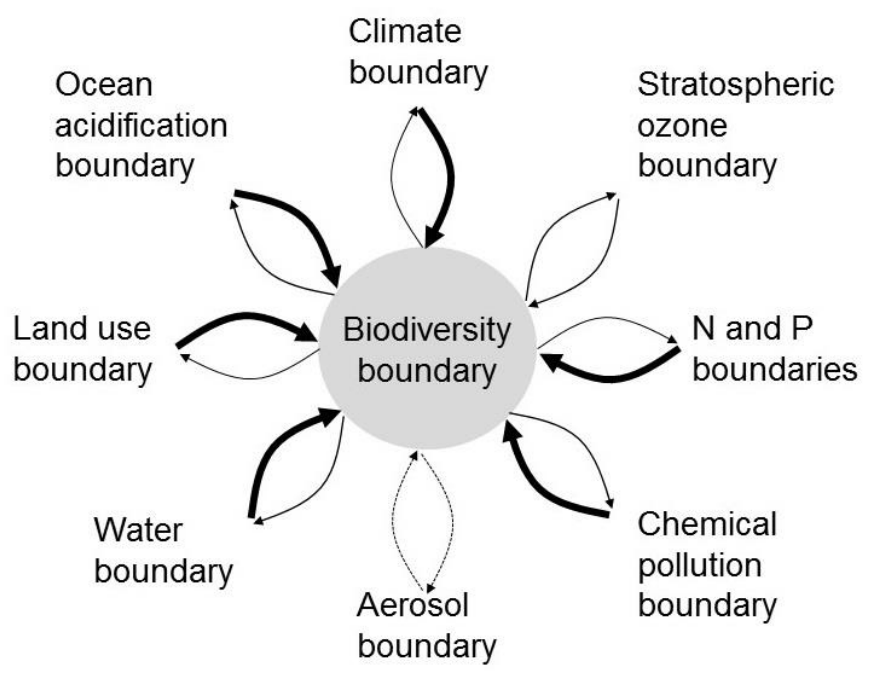

It should be recognized that, given the current knowledge about the complexity of the Earthsystem and ecosystems' dynamics, "proposed maximum levels are confounded by uncertainties, ambiguity, and subjectivity" (Hoekstra and Wiedmann, 2014). These limits may subsequently need to be converted to express environmental footprints and carrying capacities in the same units, thus introducing additional uncertainties (for instance the limit of $+2^{\circ} \mathrm{C}$ for 
climate change must be translated in emissions of $\mathrm{CO}_{2}$ equivalent to be comparable to the carbon footprint).

\subsubsection{Assignment of carrying capacities to a company}

To be ecologically sustainable, the sum of the ecological budgets allowed to the actors interacting with an ecosystem should not exceed its carrying capacities at any spatial and temporal scale. Assigning shares of carrying capacities between actors has an intrinsic political dimension. As explained by Clift et al. (2017) "a normative basis is needed for justice in the allocation of the environmental space for at least three classes of user: individuals, producing entities (e.g., industry), and governments". Various valuation principles have been proposed: the assignment between competing systems may be for instance proportional to their relative shares of gross product, of population, of historical debt, of past environmental impacts (grandfathering) or of (essential) human needs met (Bjørn, 2015; Sandin et al., 2015). A popular initiative dealing with this down-scaling issue at the company-level for climate change is the Science-based Targets initiative (Krabbe et al., 2015; Science-based Targets initiative, 2017).

As no governance process currently exists to define consensual principles for assigning ecosystems' carrying capacities, three explicit rules adapted from (Bjorn, 2015) were used in this study for down-scaling these ecological limits to company-level budgets:

(a) the assignment of carrying-capacities between sectors/activities (eg. food, transport, housing) is based on a grandfathering principle. This means that, for a given pressure driving biodiversity loss, the carrying-capacity assigned to each sector is proportional to its current relative contribution.

(b) the allocation of carrying-capacity between companies of a given sector is based on their market shares or on their respective contributions to meet human needs,

(c) all humans have the same ecological rights.

For a given impact category $\mathrm{i}$, the environmental budget $b_{i}$ assigned to a company is defined in this study as:

$$
\alpha_{i} \cdot \beta \cdot \frac{1}{p o p} \cdot C C_{i}(E q \cdot 1)
$$

where $\alpha_{i}$ is the relative contribution of the sector to the impact category $\mathrm{i}$, (dimensionless, $\alpha_{i} \in[0 ; 1]$ ),

$\beta$ is the consumer base of the company in person.year eq,

$C C_{i}$ is the carrying capacity of the ecosystems for the impact category i over one year, pop is the population size.

The ratio $C C_{i} / p o p$ can be interpreted as the individual ecological budget, assigned per person per year in order to stay within safe ecological limits. The product $\beta^{*} C C_{i} / p o p$ can thus be understood as the consumers' ecological budget. In this way, the assignment of carrying capacities to a company is based here on the definition of consumers' ecological budget and on the allocation of a fraction of this budget to the company based on its sector's footprint. 


\subsection{Operationalization in LCA-AESA}

For a given impact category $\mathrm{i}$, the footprint $f_{i}$ exerted by a business entity is interpreted as ecologically unsustainable if it is superior to its ecological budget $b_{i}$ :

$$
\begin{gathered}
f_{i}>b_{i}(\text { Eq. 2) } \\
\Leftrightarrow f_{i}>\alpha_{i} \cdot \beta \cdot \frac{C C_{i}}{p o p}
\end{gathered}
$$

As LCA models anthropic pressures driving biodiversity degradation (midpoint indicators) as well as final species loss (endpoint indicator), ecological carrying capacities can be integrated in two ways in the LCA-AESA approach. At the endpoint level, the LCA-AESA can be based on an estimation of species loss due to business activities compared to an acceptable level of degradation of biodiversity integrity. At the midpoint level, anthropic pressures responsible for biodiversity loss can be compared to ecosystems' capacities to support these pressures, which corresponds to a preventive approach. Table 2 summarizes LCA midpoint and endpoint indicators relevant for biodiversity loss for which this approach has been developed.

The Biodiversity Intactness index (BII), compatible with Recipe'08 characterization model for the endpoint Species loss, has been operationalized for LCA-AESA by Doka (2016), with a threshold value of $90 \%$. For midpoint indicators, characterization models compliant with ILCD recommendations were prioritized. These midpoints cover three out of five processes responsible of biodiversity loss: climate change, pollutions and habitat loss. Embodied Human Appropriation of Net Primary Production (eHANPP) (Haberl et al., 2012) and sea use (Langlois et al., 2015; Woods et al., 2016) might be promising approaches for assessing land-based and marine over-exploitation respectively. However, there are not yet available within the environmental impact databases that are used to perform LCA studies. Thus, no operational midpoint indicators were found for over-exploitation of the biological resources and invasive species. Despite the importance of these two processes in biodiversity degradation, they were thus not accounted for in this study.

The following indicators and their corresponding normalization references were finally chosen: Species loss, Climate change (CC), Photochemical ozone formation (POF), Terrestrial acidification (AC), Terrestrial eutrophication (EUTT), Freshwater eutrophication (EUTF), Marine eutrophication (EUTM), Freshwater ecotoxicity (FRWTOX), Land occupation (LO) and Water depletion (WD), which are directly related to processes driving biodiversity loss, as well as Ozone depletion (OD) and Soil erosion (SE) whose link to biodiversity loss is more indirect.

From a biodiversity conservation perspective, it should be noted that the relevance of thresholds' definitions varies among indicators and that uncertainties can be substantial. For instance, Marine eutrophication threshold is not specific to marine ecosystems and thus very imprecise. Besides, although Land use (LU), that estimates the deficit of soil organic carbon, is recommended by ILCD, it was not included in this study because inconsistencies were found between normalization references and the corresponding threshold. 
Table 2-LCA-AESA: ecological footprints and carrying capacities relevant for biodiversity conservation. Individual ecological budgets are from: [1] (Doka, 2016), [2] (Bjфrn and Hauschild, 2015), [3] (Sala et al., 2016) and [4] (Bjфrn, personal communication).

\begin{tabular}{|c|c|c|c|c|c|c|}
\hline \multirow[t]{2}{*}{ Level of analysis } & \multicolumn{2}{|l|}{ Ecological footprints } & \multicolumn{3}{|c|}{ Ecological carrying capacities } & \multirow{2}{*}{$\begin{array}{l}\text { Refe- } \\
\text { rences }\end{array}$} \\
\hline & $\begin{array}{l}\text { LCA impact } \\
\text { category }\end{array}$ & $\begin{array}{l}\text { Characterization } \\
\text { model }\end{array}$ & $\begin{array}{l}\text { Individual ecological } \\
\text { budget (CC/pop ratio, } \\
\text { per pers.year) }\end{array}$ & Corresponding threshold & $\begin{array}{l}\text { Relevance of the threshold for } \\
\text { biodiversity conservation objectives }\end{array}$ & \\
\hline $\begin{array}{l}\text { Impact - Biodiversity } \\
\text { loss }\end{array}$ & $\begin{array}{l}\text { Endpoint - Species } \\
\text { loss }\end{array}$ & Recipe 1.11 (2014) & $1.95 \times 10^{-5}$ species.yr & $\begin{array}{l}\text { Planetary boundary, BII at } 90 \% \\
(90 \%-30 \%) \text {, from (Steffen et al., } \\
2015)\end{array}$ & $\begin{array}{l}\text { "Losses of local species richness } \\
\text { exceeding } 20 \% \text { are likely to substantially } \\
\text { impair the contribution of biodiversity to } \\
\text { ecosystem function and services" } \\
\text { (Newbold et al., 2015) }\end{array}$ & [1] \\
\hline \multirow[t]{2}{*}{$\begin{array}{l}\text { Anthropic pressure - } \\
\text { climate change }\end{array}$} & $\begin{array}{l}\text { Midpoint - Climate } \\
\text { change }(\mathrm{CC})\end{array}$ & $\begin{array}{l}\text { GWP100 (Forster et } \\
\text { al., 2007); ILCD } \\
\text { compliant }\end{array}$ & $985 \mathrm{~kg} \mathrm{CO}_{2} \mathrm{eq}$ & $\begin{array}{l}\text { Planetary boundary, temperature } \\
\text { increase of } 2^{\circ} \mathrm{C} \text {, policy target } \\
\text { from (UNFCCC, 2010) }\end{array}$ & $\begin{array}{l}\text { A } 2^{\circ} \mathrm{C} \text { increase is predicted to trigger a } \\
\text { global extinction of } 5.2 \% \text { of species } \\
\text { (Urban, 2015). This global pressure will } \\
\text { somehow distinctively affect ecosystems } \\
\text { with harmful impacts for instance on } \\
\text { boreal biome. }\end{array}$ & {$[2]$} \\
\hline & $\begin{array}{l}\text { Midpoint - Ozone } \\
\text { depletion (ODP) }\end{array}$ & $\begin{array}{l}\text { ODP (WMO, 1999); } \\
\text { ILCD compliant }\end{array}$ & 0.078 kg CFC-11 eq & $\begin{array}{l}\text { Planetary boundary, } 7.5 \%(+/- \\
2.5 \%) \text { decrease in average ozone } \\
\text { concentration, from (Rockström } \\
\text { et al., 2009) }\end{array}$ & $\begin{array}{l}\text { Ultraviolet radiations have effects on } \\
\text { ecosystems but the ecological impacts of } \\
\text { ozone depletion are not well documented } \\
\text { (Robinson and Erickson, 2015) }\end{array}$ & {$[2]$} \\
\hline \multirow[t]{4}{*}{$\begin{array}{l}\text { Anthropic pressure - } \\
\text { pollution }\end{array}$} & $\begin{array}{l}\text { Midpoint - } \\
\text { Photochemical ozone } \\
\text { formation (POF) }\end{array}$ & $\begin{array}{l}\text { LOTOS-EUROS (van } \\
\text { Zelm et al., 2008); } \\
\text { ILCD compliant }\end{array}$ & $\begin{array}{l}\text { Global: } 3.8 \mathrm{~kg} \text { NMVOC } \\
\text { eq } \\
\text { Europe: } 2.5 \mathrm{~kg} \\
\text { NMVOC eq }\end{array}$ & $\begin{array}{l}\text { Accumulated ozone exposure, } 3 \\
\text { ppm.hour AOT40, long-term } \\
\text { policy target from the european } \\
\text { air quality directive }(2008 / \mathrm{EC} / 50)\end{array}$ & $\begin{array}{l}\text { This target aims at ensuring the protection } \\
\text { of vegetation as ground level ozone } \\
\text { affects plants growth and reproduction. }\end{array}$ & {$[2]$} \\
\hline & $\begin{array}{l}\text { Midpoint - Terrestrial } \\
\text { acidification (AC) }\end{array}$ & $\begin{array}{l}\text { Accumulated } \\
\text { exceedance (Seppälä } \\
\text { et al., 2006; Posch et } \\
\text { al., 2008); ILCD } \\
\text { compliant }\end{array}$ & $\begin{array}{l}\text { Global: } 145 \text { mole } \mathrm{H}^{+} \text {eq } \\
\text { Europe: } 89 \text { mole } \mathrm{H}^{+} \text {eq }\end{array}$ & $\begin{array}{l}\text { Average critical load of } 1,170 \\
\text { mole } \mathrm{H}^{+} \text {eq.ha }{ }^{-1} \text {.year- }{ }^{1} \text { globally } \\
\text { and } 1,100{\text { mole } \mathrm{H}^{+} \text {eq.ha }}^{-1} \text {.year- }{ }^{1} \\
\text { at the european scale, derived } \\
\text { from (Bouwman et al., 2002) }\end{array}$ & $\begin{array}{l}\text { Critical load is an estimate of the } \\
\text { pollution level under which no significant } \\
\text { impact on specific sensitive elements of } \\
\text { an ecosystem is observed. }\end{array}$ & $\begin{array}{l}{[3] \text { and }} \\
{[4]}\end{array}$ \\
\hline & $\begin{array}{l}\text { Midpoint }- \text { Terrestrial } \\
\text { eutrophication } \\
\text { (EUTT) }\end{array}$ & $\begin{array}{l}\text { Accumulated } \\
\text { exceedance (Seppälä } \\
\text { et al., 2006; Posch et } \\
\text { al., 2008); ILCD } \\
\text { compliant }\end{array}$ & $\begin{array}{l}\text { Global: } 887 \text { mole } \mathrm{N} \text { eq } \\
\text { Europe: } 577 \text { mole } \mathrm{N} \text { eq }\end{array}$ & $\begin{array}{l}\text { Average critical load of } 1,340 \\
\text { mole } \mathrm{N} \text { eq.ha }{ }^{-1} \text {.year }{ }^{1} \text { globally }^{-1} \\
\text { and } 1,390 \text { mole } \mathrm{N} \text { eq.ha }^{-1} \text {.year- }{ }^{1} \text { at } \\
\text { the european scale, derived from } \\
\text { (Bouwman et al., 2002) }\end{array}$ & $\begin{array}{l}\text { Excess nitrogen is a major threat to } \\
\text { biodiversity (SCDB, 2010). }\end{array}$ & $\begin{array}{l}{[3] \text { and }} \\
{[4]}\end{array}$ \\
\hline & $\begin{array}{l}\text { Midpoint - } \\
\text { Freshwater } \\
\text { eutrophication } \\
\text { (EUTF) }\end{array}$ & $\begin{array}{l}\text { EUTREND model as } \\
\text { implemented in } \\
\text { Recipe (Struijs et al., } \\
\text { 2009); ILCD } \\
\text { compliant }\end{array}$ & $\begin{array}{l}\text { Global: } 0.84 \mathrm{~kg} \mathrm{P} \text { eq } \\
\text { Europe: } 0.46 \mathrm{~kg} \text { P eq }\end{array}$ & $\begin{array}{l}\text { Freschwater phosphorus } \\
\text { concentration threshold of } 0.3 \\
\text { mg/L integrated at the global and } \\
\text { european scale, from (Struijs et } \\
\text { al., 2011) }\end{array}$ & $\begin{array}{l}\text { A large field study showed that } \mathrm{P} \\
\text { concentration above } 0.3 \mathrm{mg} / \mathrm{L} \text { impairs } \\
\text { macroinvertebrate genera occurrence in } \\
\text { dutch inland waters (Struijs et al., 2011) }\end{array}$ & {$[2]$} \\
\hline
\end{tabular}




\begin{tabular}{|c|c|c|c|c|c|c|}
\hline & $\begin{array}{l}\text { Midpoint - Marine } \\
\text { eutrophication } \\
\text { (EUTM) }\end{array}$ & $\begin{array}{l}\text { EUTREND model as } \\
\text { implemented in } \\
\text { Recipe (Struijs et al., } \\
\text { 2009); ILCD } \\
\text { compliant }\end{array}$ & $\begin{array}{l}\text { Global: } 29 \mathrm{~kg} \mathrm{~N} \text { eq } \\
\text { Europe: } 31 \mathrm{~kg} \mathrm{~N} \text { eq }\end{array}$ & $\begin{array}{l}\text { Coastal waters nitrogen } \\
\text { concentration threshold of } 1.75 \\
\mathrm{mg} / \mathrm{L}(+/-0.75 \mathrm{mg} / \mathrm{L}) \text { integrated } \\
\text { by the global and european } \\
\text { coastal volumes, from (de Vries } \\
\text { et al., 2013) }\end{array}$ & $\begin{array}{l}\text { The threshold has been estimated from } \\
\text { ecological and toxicological studies, } \\
\text { national surface water quality standards } \\
\text { and European objectives, but is not } \\
\text { specific to marine ecosystems. }\end{array}$ & [2] \\
\hline & $\begin{array}{l}\text { Midpoint - } \\
\text { Freshwater } \\
\text { ecotoxicity } \\
\text { (FRWTOX) }\end{array}$ & $\begin{array}{l}\text { USEtox model } \\
\text { (Rosenbaum et al., } \\
\text { 2008); ILCD } \\
\text { compliant }\end{array}$ & $\begin{array}{l}\text { Global: } 1.87 \times 10^{4} \\
\text { [PAF].m3.day } \\
\text { Europe: } 1.03 \times 10^{4} \\
{[\text { PAF].m3.day }}\end{array}$ & $\begin{array}{l}\text { HC5(NOEC), used in the EU } \\
\text { Water Framework Directive to } \\
\text { define environmental quality } \\
\text { standards }\end{array}$ & $\begin{array}{l}\text { HC5(NOEC) corresponds to "the } \\
\text { concentration at which maximum 5\% of } \\
\text { species are affected above their no } \\
\text { observable effect concentration level" } \\
\text { (Bjørn, Diamond, Birkved, \& Hauschild, } \\
2014 \text { ) }\end{array}$ & [2] \\
\hline \multirow[t]{4}{*}{$\begin{array}{l}\text { Anthropic pressure - } \\
\text { habitat loss and } \\
\text { degradation }\end{array}$} & $\begin{array}{l}\text { Midpoint - Soil } \\
\text { erosion (SE) }\end{array}$ & $\begin{array}{l}\text { Model based on soil } \\
\text { erosion (Saad et al., } \\
\text { 2013); not } \\
\text { recommended by } \\
\text { ILDC }\end{array}$ & $\begin{array}{l}\text { Global: } 1.8 \text { tonnes } \\
\text { eroded soil } \\
\text { Europe: } 1.2 \text { tonnes } \\
\text { eroded soil }\end{array}$ & $\begin{array}{l}\text { Tolerable average soil erosion of } \\
0.85 \text { t.ha }^{-1} \text {.year- }{ }^{-1}(+/-0.55 \text { ton.ha } \\
\left.{ }^{1} \text {.year- }{ }^{1}\right) \text {, from (Verheijen et al., } \\
2009)\end{array}$ & $\begin{array}{l}\text { The threshold corresponds to an } \\
\text { equilibrium with the average soil } \\
\text { formation rate and thus not explicitly } \\
\text { linked to biodiversity conservation. }\end{array}$ & {$[2]$} \\
\hline & Midpoint - Land use & $\begin{array}{l}\text { Model based on soil } \\
\text { organic matter (Milà I } \\
\text { Canals et al. 2007); } \\
\text { ILCD compliant }\end{array}$ & $\begin{array}{l}\text { Global: } 1,99 \times 10^{4} \mathrm{~kg} \mathrm{C} \\
\text { deficit } \\
\text { Europe: } 8,12 \times 10^{3} \mathrm{~kg} \mathrm{C} \\
\text { deficit }\end{array}$ & Based on soil erosion threshold & $\begin{array}{l}\text { No explicit link to biodiversity } \\
\text { conservation }\end{array}$ & $\begin{array}{l}{[3] \text { and }} \\
{[4]}\end{array}$ \\
\hline & $\begin{array}{l}\text { Midpoint - Land } \\
\text { occupation (LO) }\end{array}$ & $\begin{array}{l}\text { LCI land occupation; } \\
\text { not recommended by } \\
\text { ILDC }\end{array}$ & $\begin{array}{l}\text { Global: } 1.5 \times 10^{4} \\
\text { m2.year } \\
\text { Europe: } 9.5 \times 10^{3} \\
\text { m2.year }\end{array}$ & $\begin{array}{l}\text { Protection of } 31 \% \text { of terrestrial } \\
\text { areas (managed with conservation } \\
\text { of nature as a primary objective), } \\
\text { median of estimates compiled by } \\
\text { (Noss et al., 2012) }\end{array}$ & $\begin{array}{l}\text { This threshold is actually lower than the } \\
\text { recommendations of Noss et al. (2012) } \\
\text { who argue that from a "precautionary } \\
\text { perspective, } 50 \%[\ldots] \text { is scientifically } \\
\text { defensible as a global target". }\end{array}$ & [2] \\
\hline & $\begin{array}{l}\text { Midpoint - Water } \\
\text { depletion (WD) }\end{array}$ & $\begin{array}{l}\text { Ecological Scarcity } \\
\text { Method (Frischknecht } \\
\text { et al., 2008); ILCD } \\
\text { compliant }\end{array}$ & $\begin{array}{l}\text { Global: } 99.3 \mathrm{~m}^{3} \text { water } \\
\text { eq } \\
\text { Europe: } 159 \mathrm{~m}^{3} \text { water } \\
\text { eq }\end{array}$ & $\begin{array}{l}\text { Conservation of } 87 \% \text { of } \\
\text { accessible blue water resources } \\
\text { worldwide, from (Gerten et al., } \\
2013 \text { ) }\end{array}$ & $\begin{array}{l}\text { Precautionary estimation of } \\
\text { environmental flow requirements which } \\
\text { represent "the blue water needed to } \\
\text { sustain aquatic ecosystem functions" and } \\
\text { additional safe margin to reflect the risk } \\
\text { of water stress. }\end{array}$ & $\begin{array}{l}\text { [3] and } \\
{[4]}\end{array}$ \\
\hline $\begin{array}{l}\text { Anthropic pressure - } \\
\text { overexploitation }\end{array}$ & None identified & & & & & \\
\hline $\begin{array}{l}\text { Anthropic pressure - } \\
\text { invasive species }\end{array}$ & None identified & & & & & \\
\hline
\end{tabular}




\section{Materials and methods}

\subsection{Case study}

This study is part of a research-intervention project with the mass market retail company Casino France, which ran from November 2015 to October 2016, aiming at assessing the ecological performance of its CSR action plan and at supporting the definition of strategic orientations to integrate biodiversity issues. The main objectives were:

- to assess the anthropic pressures associated with biodiversity loss for activities identified as environmental hotspots,

- to assess whether these pressures were ecologically sustainable,

- to identify the drivers of the most critical pressures.

Casino France owns about 7,500 stores ranging from small urban stores to hypermarkets, and represents 10 billion $€$ of sales (Groupe Casino, 2016). It targets a large variety of consumers with products at an affordable price.

\subsection{Scope and functional unit}

A qualitative mapping of the pressures potentially exerted on biodiversity along the company's value chain was performed based on a literature review. It suggested that the retailer had quite limited direct ecological impacts but had substantial indirect impacts on biodiversity through the products it delivers. Food products were found to be simultaneously preponderant from an economic and environmental point of view, dominating the sales as well as the scope 3 of the company's carbon footprint (Groupe Casino, personal communication). Consequently, the scope of study was restricted to the food products portfolio. Agriculture production is identified as the main hotspot in the environmental footprint of food products and as the primary single driver of biodiversity loss, with quite a strong scientific consensus (Colomb et al., 2015b; Kok et al., 2014; Notarnicola et al., 2017; Steinfeld et al., 2006). So, the scope of the quantitative assessment was circumscribed to the food portfolio of product $(\mathrm{PoP})$ at the agricultural production phase. Because of its restrictive scope, this assessment underestimates the total pressures exerted on biodiversity by the company and its value chain but could set a baseline to appreciate distances from ecological boundaries.

Thus, the functional unit of this study can be defined as "to produce from cradle-to-farm-gate the food Portfolio of products (PoP) that was delivered by CASINO France over a 1-year time interval".

\subsection{Assessment of the pressures exerted on biodiversity}

The main steps for the calculation of the ecological impacts of the retailer food PoP at the agricultural phase were:

- division of the food PoP in product categories at a relevant level of definition (section 3.3.1),

- definition of a typology of agricultural products and selection of reference products from a consistent LCI database (section 3.3.2)

- inference of the raw agricultural products needed to produce the food PoP (section 3.3.3), 
- calculation of the ecological impacts associated to the food PoP at the agricultural phase (section 3.3.4)

\subsubsection{Primary data}

A description of the food PoP of the retailer at the product level has been used as primary data (more than 50,000 food references). It corresponds to the quantities of products at the gate of warehouses over 12 months during the 2015-2016 period. The retailer's products classification served as a basis to aggregate the products in a manageable number of categories. In total, 880 categories of human and pet food products, representing more than $95 \%$ of the total mass of the food PoP, have been analyzed following the procedure detailed in the next sections.

\subsubsection{LCI database and agricultural products typology}

Based on the information supplied by the retailer, a majority of products appeared to be produced in France or in Europe. The life cycle inventory (LCI) database Agribalyse was subsequently selected as it provides a homogeneous database of more than 100 animal and plant products mainly produced in France at the perimeter cradle-to-farm-gate (Colomb et al., 2015a; Koch and Salou, 2015).

The typology of agricultural products was defined in line with the level of details of the Agribalyse database and of the ingredients content of the food PoP (for details see the Electronic supplementary material (ESM)). Considering the large number of products and the precision of products specifications at the PoP level of analysis, it was not possible to distinguish between production modes. As Casino France has a mass-market positioning, we assumed that the share of the different production modes (conventional, organic, quality labels...) was similar to the average french production mix. Thus, each time Agribalyse provided a national average LCI, it was used as a reference.

\subsubsection{Inference of the quantity of agricultural products}

The framework used for modelling the agricultural products that were needed to produce the retailer's food portfolio is illustrated by Figure 3. Thanks to standard recipes or ingredients information that are available on the products, the food product portfolio was successively translated to amounts of ingredients and then, thanks to bibliographic study, into amounts of raw agricultural products. References are listed in ESM, Tables S2 and S3.

Figure 3 - Modelling framework of the agricultural products quantities that correspond to the retailer's food product portfolio. Two examples, orange juice and cake, are provided (for values' references, see ESM)

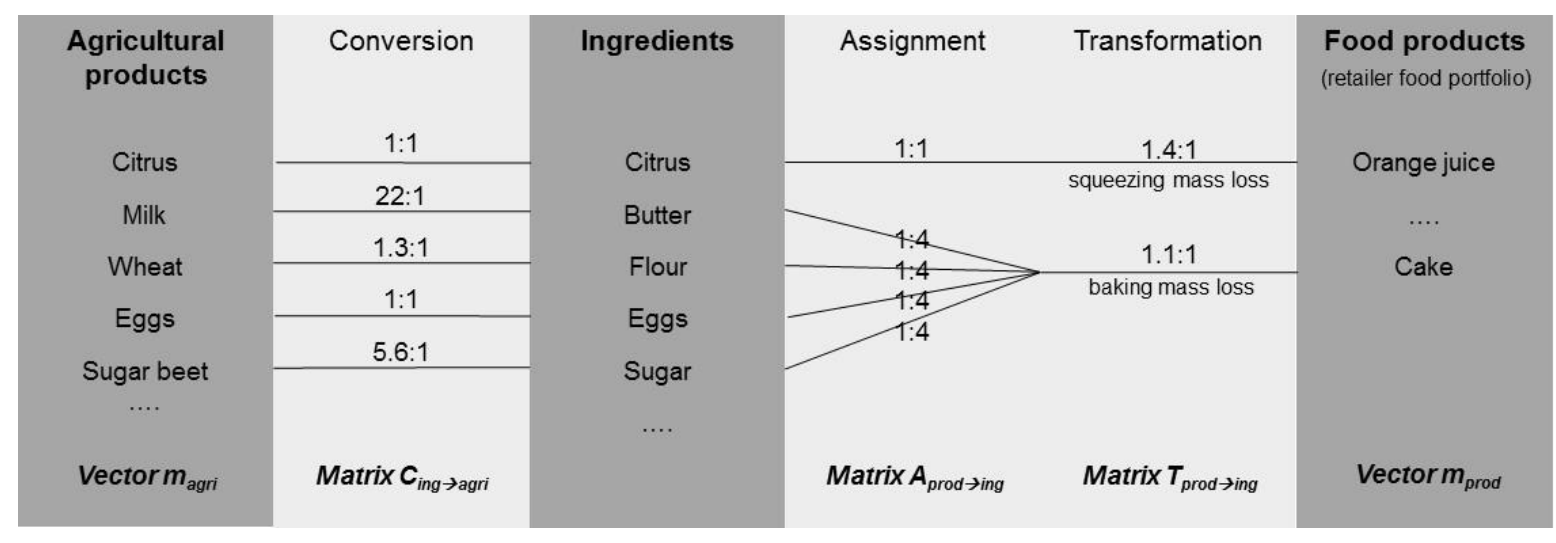


In this study, $\mathrm{n}$ refers to the number of food product categories of the retailer's portfolio, $\mathrm{m}$ to the number of ingredients and $p$ to the number of agricultural products considered (in this study $\mathrm{n}=880, \mathrm{~m}=44, \mathrm{p}=39$ ). The vector $\mathrm{m}_{\text {prod }}$ of size $\mathrm{n}$ corresponds to the quantities $(\mathrm{kg})$ of retailer's food products. Aprod $\rightarrow$ ing is the assignment matrix of $\mathrm{n}$ rows and $\mathrm{m}$ columns that represents the average proportions of ingredients in each product category (the recipe), such as for any product $\mathrm{i}$ in $[1, \mathrm{n}] \sum_{\mathrm{j}} \mathrm{A}_{\text {prod } \rightarrow \text { ing }} \mathrm{ij}=1$. The proportions of ingredients have been estimated based on traditional recipes and content information for retailer's brand products. $\mathrm{T}_{\text {prod } \rightarrow \text { ing }}$ is the transformation matrix of $\mathrm{n}$ rows and $\mathrm{m}$ columns that represents the inverse of the mass loss rates consequent to the transformation of the ingredient mix in the final product (eg. mass loss associated with baking or drying) (for the conventions used see ESM). $A_{\text {prod } \rightarrow \text { ing }}{ }^{\circ} T_{\text {prod } \rightarrow \text { ing }}$ is the Hadamard product (element-wise multiplication) of the two matrices. $\mathrm{C}_{\mathrm{ing} \rightarrow \text { agri }}$ is the conversion matrix of $\mathrm{m}$ rows and $\mathrm{p}$ columns that represents the inverse of the yield factors from raw agricultural products to ingredients (for the conventions used see ESM). The vector $m_{\text {agri }}$ representing the agricultural products quantities $(\mathrm{kg})$ is estimated by:

$\mathrm{m}_{\text {agri }}=\mathrm{m}_{\text {prod }}\left(\mathrm{A}_{\text {prod } \rightarrow \text { ing }}{ }^{\circ} \mathrm{T}_{\text {prod } \rightarrow \text { ing }}\right) \mathrm{C}_{\text {ing } \rightarrow \text { agri }}$

This model ignores the potential losses that may occur along the supply chain (during the transformation, transport, and storage for example). This leads to an underestimation of the total pressures exerted on biodiversity.

\subsubsection{Assessment of the ecological impacts of the food product portfolio}

The life cycle impact assessment (LCIA) of reference Agribalyse products was performed per $\mathrm{kg}$ of product with OpenLCA, using Agribalyse database v1.2 and ecoinvent v.2.2 as background database. The characterizations models used to estimate the ecological impacts are those described in Table 2 (minor modifications are reported in ESM).

These LCIA were used to calculate the ecological impact intensities per $\mathrm{kg}$ of agricultural products. We thus obtained $\mathrm{I}_{\mathrm{agri}}$, a matrix of $\mathrm{p}$ lines and $\mathrm{q}$ columns, where $\mathrm{q}$ is the number of impact indicators $(\mathrm{q}=12)$, that represents the ecological impact intensities per $\mathrm{kg}$ of agricultural products (provided in the ESM). The matrix F representing the environmental footprints of the food PoP per agricultural products (expressed in the respective units of the impact indicators) is estimated by:

$\mathrm{F}=\operatorname{diag}\left(\mathrm{m}_{\mathrm{agri}}\right) \mathrm{I}_{\mathrm{agri}}$

\subsection{Carrying capacity assignment}

Table 3 summarizes how the rules defined in Section 2.3 to assign ecological budgets to a company were applied to this case study.

Since the scope of analysis is restricted to the agricultural production step, the sectoral allocation factors $\left(\alpha_{i}\right)$ were estimated based on agriculture's contribution to ecological pressures in Europe. These values were derived from three different assessments: basket of products (BoP) analysis (Notarnicola et al., 2017; Sala et al., 2016), consumption areas (Tukker et al., 2006) and sectoral emissions (Leip et al., 2015) (see ESM).

Following rule (b), the market share of Casino France in food retail was estimated and subsequently expressed in person.year equivalent to reflect the theoretical number of persons fully fed by the company. $\beta$ was estimated to be about 2.9 million person.year eq. (see ESM). 
Regarding rule (c), we referred to the individual ecological budgets specified in Table 2 for Europe as this study is related to food products sold in France and mainly produced in Europe. It should be noted that flows related to rainforests transformation were identified at the LCI step, highlighting that ecosystems beyond european borders were affected. Because european ratios were on average more stringent than global ratios, using european values can be considered as a precautionary approach.

Table 3 - Application of the rules used to downscale ecosystems' carrying capacities at the business-level to the case study.

\begin{tabular}{|l|l|l|l|}
\hline $\begin{array}{l}\text { Rules for } \\
\text { assigning } \\
\text { carrying } \\
\text { capacities to a } \\
\text { company }\end{array}$ & $\begin{array}{l}\text { (a) Assignment between } \\
\text { sectors is based on a } \\
\text { grandfathering principle }\end{array}$ & $\begin{array}{l}\text { (b) Assignment between } \\
\text { companies of a given } \\
\text { sector is based on their } \\
\text { market shares / their } \\
\text { respective contributions to } \\
\text { meet human needs }\end{array}$ & $\begin{array}{l}\text { (c) All human } \\
\text { beings of a } \\
\text { given region } \\
\text { have the same } \\
\text { budgets }\end{array}$ \\
\hline $\begin{array}{l}\text { Budget }\left(\boldsymbol{b}_{\boldsymbol{i}}\right) \\
\text { components }\end{array}$ & $\begin{array}{l}\boldsymbol{\alpha}_{\boldsymbol{i}} \text { is the relative } \\
\text { contribution to impact i } \\
\text { of the sector of the entity } \\
\text { under study }\end{array}$ & $\begin{array}{l}\boldsymbol{\beta} \text { is the consumer base of } \\
\text { the company in } \\
\text { person.year eq }\end{array}$ & $\begin{array}{l}\boldsymbol{C} \boldsymbol{C}_{i} / \text { pop } \text { is the } \\
\text { carrying } \\
\text { capacity } \\
\text { allocated to } \\
\text { each person }\end{array}$ \\
\hline $\begin{array}{l}\text { Application to } \\
\text { the case study }\end{array}$ & $\begin{array}{l}\text { Agriculture's } \\
\text { contribution to total } \\
\text { european impacts for } \\
\text { each impact category } \\
\text { (from different sources, } \\
\text { see ESM) }\end{array}$ & $\begin{array}{l}\text { Equivalent number of } \\
\text { persons fully fed by the } \\
\text { company }\end{array}$ & $\begin{array}{l}\text { From } \\
\text { literature (see } \\
\text { Table 2) }\end{array}$ \\
\hline
\end{tabular}

\subsection{Criterion for detecting unsustainability}

For a given impact category $\mathrm{i}$, the footprint $f_{i}$ exerted by a business entity is interpreted as ecologically unsustainable if it is superior to its ecological budget $b_{i}$ (Cf. Eq. 2).

The product $\beta^{*} C C_{i} /$ pop can be interpreted as the consumers' ecological budget. It is the amount of environmental impact $\mathrm{i}$ assigned to the individuals making up the consumer base of the considered company for all their needs (food, housing, mobility, health...). The ecological impacts of the food PoP at the agricultural phase were normalized by the consumers' ecological budgets. This measures the Occupation of the Consumers' ecological Budgets $\left(\mathrm{OCB}_{\mathrm{i}}\right)$ :

$$
\begin{aligned}
(E q .2) & \Leftrightarrow \frac{f_{i}}{\beta \cdot C C_{i} / p o p}>\alpha_{i} \\
& \Leftrightarrow O C B_{i}>\alpha_{i}
\end{aligned}
$$

For each impact category $i$, the $\mathrm{OCB}_{\mathrm{i}}$ was finally compared to the share of carrying capacity assigned to agriculture production $\alpha_{i}$ to assess absolute ecological sustainability.

\subsection{Sensitivity analysis}

A sensitivity analysis was performed in order to assess the robustness of our conclusions by modifying two key hypothesis (see ESM). As the model presented in Section 3.3.3 does not account for co-products, it probably overestimates the amount of milk needed to make up the 
food PoP. Based on a fat mass balance analysis, it was estimated that the quantity of milk could be up to $38 \%$ lower than the modeled value. The other sensitive hypothesis is related to the agricultural products for which no proper reference was found in Agribalyse database. The method to account for these products was modified in order to estimate an error range of their ecological impact intensities per $\mathrm{kg}$. These two changes of hypothesis were cross-tested. This allowed us to estimate the results uncertainties presented in the next section.

\section{Results and discussion}

\subsection{Detection of unsustainable pressures exerted on biodiversity}

Unsustainability of the pressures exerted on biodiversity by the food portfolio of Casino France at the agricultural phase was assessed based on Eq. 2. Figure 4 shows that the normalized impacts, which can be interpreted as the Occupation of the Consumers' ecological Budget (OCB), vary greatly between impact categories. Two incremental levels of unsustainability are distinguished:

- exceedance of the fraction of the consumers' ecological budget allocated to agriculture production ( $\alpha$ factor, materialized by colored marks)

- and exceedance of the entire consumers' ecological budget, which means that the footprint exceeds the total budget of the company's consumer base (materialized by a red dotted line).

For the endpoint Species loss as well as for four midpoint indicators - climate change, photochemichal ozone formation, soil erosion and water depletion - the OCB was found to exceed $100 \%$. This means that the agriculture production step alone exerts more impacts than what is defined as permissible to cover all the needs of the consumers. These impacts can thus be qualified as unsustainable considering the ecosystems' carrying capacities used in this study. Water depletion unsustainability might even be more significant as Agribalyse life cycle inventory does not account for all water flows (Koch and Salou, 2015).

The fractions of the carrying capacities assigned to agriculture production based on its current share of environmental impacts in EU show some differences between the methods but were close enough to provide a consistent interpretation regarding the level of unsustainability (Figure 4). Two normalized pressures were found to be inferior to the consumers' ecological budgets but superior to the fraction allocated to agriculture production: freshwater ecotoxicity and freshwater eutrophication. Thus, based on a grandfathering principle, these pressures can also be considered as ecologically unsustainable.

Terrestrial and freshwater ecosystems appear to be both under unsustainable level of pressures for all three out of five categories of anthropic pressures driving biodiversity loss evaluated in this study. Indeed, terrestrial ecosystems are potentially affected by climate change, groundlevel ozone and to some extent by soil erosion; and freshwater ecosystems are potentially affected by climate change, freshwater eutrophication and ecotoxicity, as well as water depletion. These results support the idea that agriculture production has major impacts on biodiversity (Kok et al., 2014). 
Figure 4 -Identification of the pressures exerted at unsustainable levels by the food products portfolio of the retailer at the agriculture phase. The barplot represents the occupation of the consumers' ecological budgets (OCB) and error bars indicate the minimum and maximum values estimated with the sensitivity analysis. Colored marks correspond to sustainability thresholds (sectoral allocation factors $\alpha$ ) derived from three different methods. (CC: climate change, ODP: ozone depletion, POF: photochemical ozone formation, AC: terrestrial acidification, EUTT: terrestrial eutrophication, EUTF: freshwater eutrophication, EUTM: marine eutrophication, FRWTOX: freshwater ecotoxicity, LO: land occupation, SE: soil erosion and WD: water depletion)

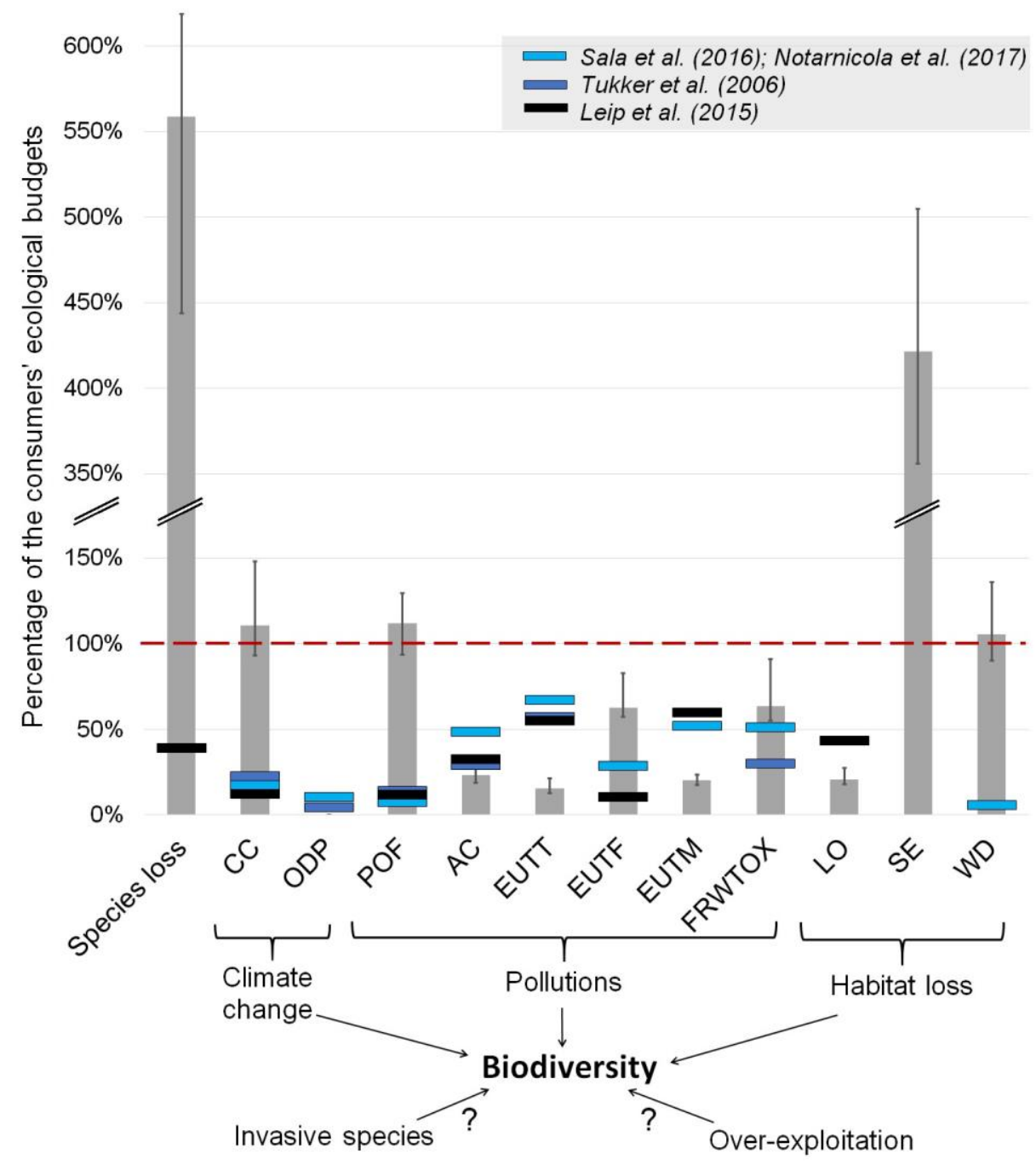

\subsection{Agricultural categories contribution}

Agricultural products contribute to different extents to the assessed pressures (Figure 5). Animal products have globally the strongest impacts. Freshwater ecotoxicity is the only ecological pressure for which plant products have a more important contribution than animal products, with grapes, citruses and coffee representing respectively $19 \%, 16 \%$ and $10 \%$ of the pressure. Freshwater eutrophication is found to be especially affected by farmed fish (32\%). For the other midpoint impact categories which were characterized as unsustainable (CC, POF, SE and WD), beef meat and milk represented together between $31 \%$ (for WD) and 59\% (for $\mathrm{CC}$ ) of the pressure. For the endpoint species loss, animal products largely dominate, with bovine products (meat and milk) contributing at $49 \%$. 
Figure 5 - Relative contribution of the agricultural products categories to the ecological impacts (CC: climate change, ODP: ozone depletion, POF: photochemical ozone formation, $A C$ : terrestrial acidification, EUTT: terrestrial eutrophication, EUTF: freshwater eutrophication, EUTM: marine eutrophication, FRWTOX: freshwater ecotoxicity, LO: land occupation, SE: soil erosion and WD: water depletion).

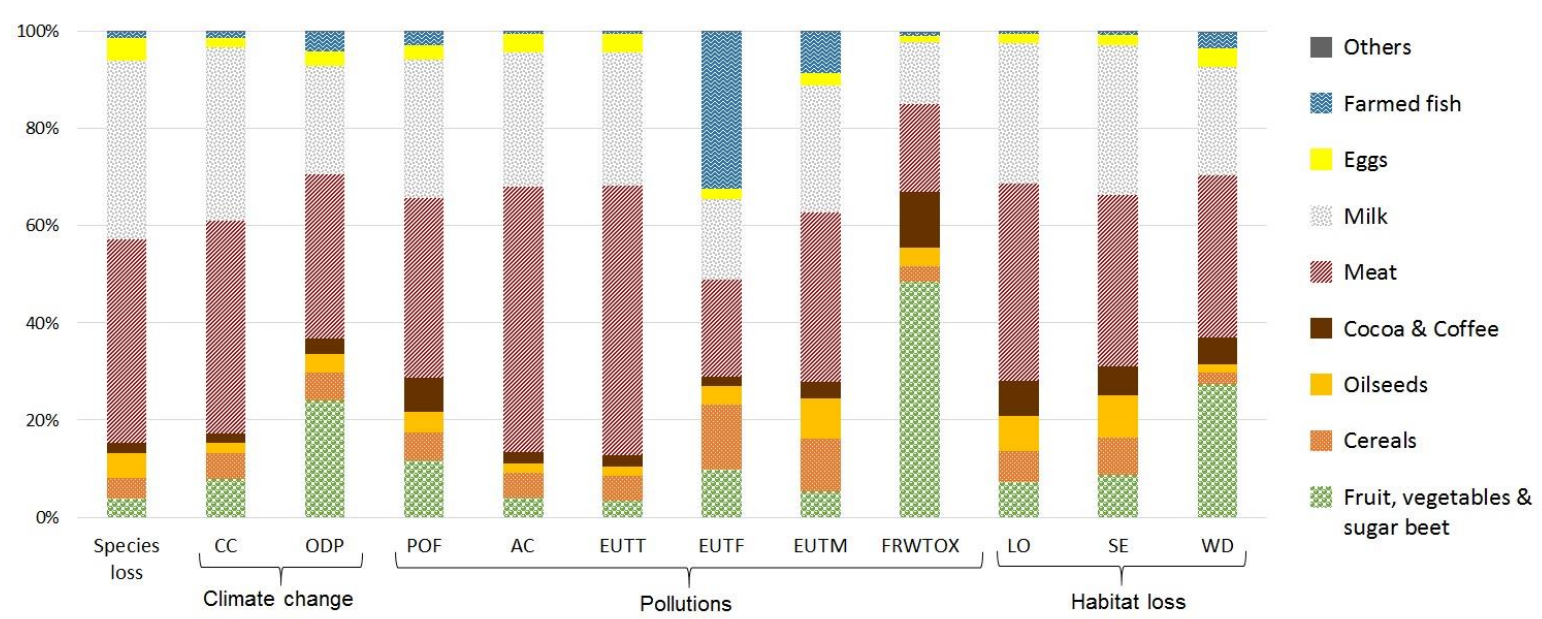

These results are in line with previous studies that identified livestock production as the top driver of terrestrial biodiversity loss (Machovina et al., 2015; Reid et al., 2010). It should be stressed that the impacts of wild fish catches have not been assessed in this study although it is potentially associated with unsustainable pressures related to stocks over-exploitation. Pressures associated with fish farming are also probably underestimated, as fish for which wild or farm origin was not known was not accounted for.

\subsection{Results robustness}

Results obtained with the LCA-AESA method suggest that the following anthropic pressures are ecologically unsustainable and are thus to be tackled in priority: soil erosion, climate change, water depletion, photochemichal ozone formation, freshwater ecotoxicity and freshwater eutrophication. These pressures found to be ecologically unsustainable do not match with the environmental mechanisms that contribute the most to the endpoint Species loss namely: natural land transformation, agricultural land occupation and climate change (Table 4). There is thus an apparent discrepancy between the two methods on what are the main threats to biodiversity conservation.

Recipe species loss endpoint method suggests that the first cause of the unsustainable loss of biodiversity is related to terrestrial habitat loss, which is in line with the work of Alkemade et al. (2009) and Kok et al. (2014), while the LCA-AESA method does not point out land occupation associated with agricultural production as ecologically unsustainable. We believe that the significance of land occupation is downplayed in the present LCA-AESA approach due to a permissive normalization reference (Table 2). Indeed Noss et al. (2012) recommended that $50 \%$ of land would be protected while Bjørn and Hauschild (2015) set the threshold to $31 \%$. Setting the threshold at $50 \%$ would be more consistent with the application of the precautionary principle, as recommended by (Ryberg et al., 2016). It would also be more in line with the LCA characterization method that is based on LCI of land occupation and thus does not take into account adjacent lands affected by fragmentation. 
Conversely, freshwater ecotoxicity and freshwater eutrophication are found to be secondary drivers of biodiversity erosion with the Species loss endpoint method while they are characterized as unsustainable with the LCA-AESA method. Direct observations of freshwater ecosystems in France mainland territory tend to support that these ecosystems are indeed locally under pressures exceeding their carrying capacities (Commissariat Général au Développement Durable, 2016). For instance, between 2012 and 2015, France has experienced each year drought crises leading to water restrictions for agriculture use affecting between $7 \%$ and $34 \%$ of its departments each year. Pesticides are found in almost all streams with an average concentration superior to quality standards for $24 \%$ of monitored sectors. Regarding freshwater eutrophication, phosphate concentrations (driven both by fertilizer use and urban wastewater discharge) are found to exceed the limit defining good ecological state for $14.5 \%$ of monitored spots.

Table 4 -Relative contribution of the environmental mechanisms to the endpoint Species loss.

\begin{tabular}{|l|l|c|}
\hline Habitat loss & $\begin{array}{l}\text { Natural land transformation } \\
\text { Transformation, from tropical rain forest } \\
\text { Transformation, from forest }\end{array}$ & $\begin{array}{c}57 \% \\
46 \%\end{array}$ \\
\cline { 2 - 3 } & $\begin{array}{l}\text { Agricultural land occupation } \\
\text { Occupation, arable } \\
\text { Occupation, pasture and meadow, extensive }\end{array}$ & $11 \%$ \\
\cline { 2 - 3 } & Urban land occupation & $33 \%$ \\
& $22 \%$ \\
\hline \multirow{2}{*}{$\begin{array}{l}\text { Climate change } \\
\text { Methane, biogenic }\end{array}$} & $8 \%$ \\
\hline Pollutions & Terrestrial ecotoxicity & $3 \%$ \\
\cline { 2 - 3 } & Freshwater ecotoxicity, freshwater eutrophication, & $1 \%$ \\
\cline { 2 - 3 } & marine ecotoxicity and terrestrial acidification & $<0.1 \%$ \\
\hline
\end{tabular}

In fact, each approach answers a different question. For the endpoint Species loss as modeled by Recipe, the question is: "How many species are affected?" All species are considered as equally important. As the impacts on terrestrial, marine and freshwater ecosystems are aggregated after being weighted by the number of known species in these compartments (1.6 million, 0.25 million and 0.1 million species respectively) impacts on terrestrial ecosystems overshadow the impacts on aquatic ecosystems. Furthermore, the endpoint species loss is modeled as a linear, incremental response to stresses. On the other side, LCA-AESA method, applied at a midpoint level, answers whether the exerted anthropic pressures are likely to reach levels exceeding ecosystems carrying capacities. It is plausible that when approaching or crossing a boundary the LCA linear model for species loss become obsolete as systemic shifts might happen. The complementarity of both approaches should be examined deeper.

\subsection{Strategic perspectives for decision-makers}

This study focused on the food portfolio of a french mass-retail company. The results of this case study suggest that several pressures generated by the production of these food products are not ecologically sustainable, as the total consumers' ecological budgets are already exceeded for several pressures at the agricultural step.

Based on the study results, previous work on the reduction of food ecological impacts (Garnett, 2011; Machovina et al., 2015; Notarnicola et al., 2017; WRI, 2016) and the biodiversity mitigation hierarchy (Phalan et al., 2017), a comprehensive strategy was proposed to the company. It follows three complementary and prioritized orientations: (1) adjustments to 
nutritional needs, (2) substitution of most impacting agricultural segments by low impact products (e.g. more efficient protein sources), and (3) improvement of the ecological performance of production modes. This hierarchy is quite consistent with the prioritization of low GHG food behaviors by Garnett as eating "no more than needed to maintain a healthy body weight" and eating "fewer meat and dairy products" were identified as the two top priorities (Garnett, 2011).

The rationale of the first proposition is that designing an offer adapted to nutritional needs could simultaneously improve ecological and health impacts by limiting over-consumption (and thus unnecessary production) (Tilman and Clark, 2014). Its implementation would rely on demandside measures supported by marketing and quality departments. The motivation for the second orientation is that, given the gap with sustainability, switching from high impact product categories to more eco-efficient categories (e.g. from beef proteins to pea proteins) might lead to faster and cheaper gains than improving the poor performance of impacting categories. The implementation of this second strategic proposition might be especially touchy as it would rely simultaneously on demand-side (consumption shifts) and production-side measures (restructuration). Such changes would involve a diversity of institutional, economic and territorial stakeholders. If this second proposition decreases the cost of the average basket of product (which is supported by WRI (2016) estimations of proteins costs), this improvement of the customers' purchasing power could support the generalization of environmental quality oriented products (third orientation) that are usually more expensive than conventional agriculture products. Tracking qualitative improvements of production modes would require an increased traceability of particular production schemes. Because collection and transmission of information introduce transaction costs, this third proposition would probably rely on ecocertifications and labels.

The strategic orientations proposed cannot be implemented by a company alone. Sectoral and public policy supports are needed. As the portfolio of Casino France is quite representative of the food mass-market products sold in France, the findings of this study might also have implications for companies in the same market segment. This strategy opens-up perspectives to take actions in favor of biodiversity conservation not only at a local scale but also at a more systemic level.

\subsection{Research and institutional perspectives}

In this paper, compliance with the ecosystems' carrying capacities assigned to the company is considered as a prerequisite for business activities to be compatible with biodiversity conservation. In line with the planetary boundaries and AESA frameworks from which it derives, the method builds on the concept of "strong sustainability" as it does not allow for trade-off between processes driving biodiversity loss. It relies on the assumption that crossing collectively any boundary could potentially triggers ecosystemic shifts that would jeopardize biodiversity conservation objectives. While its application has highlighted its relevance for decision-makers, technical limits as well as governance challenges still need to be addressed to make this approach fully operational.

Spatial resolution. The method refers to average carrying capacities that may hide exceedances of ecological limits at a lower spatial resolution (Ryberg et al., 2016). To be considered as sustainable, business activities should comply "with the carrying capacity constraints at both global and local ecosystem level” (Repar et al., 2017). This is the main reason why in this study 
the criterion comparing the company's footprints and ecological budgets is used to detect global unsustainability and not to demonstrate sustainability. As improvements are made in products traceability and LCA regionalization, it will become meaningful to derive ecological boundaries at local scale especially for the pressures whose impacts are mainly at an infra-regional scale (like water depletion and land occupation).

Coverage of biodiversity loss drivers. Not all relevant pressures were assessed in this study. Over-exploitation of the biological resources, invasive species, habitat fragmentation, as well as physical pollutions like light pollution are not modeled in the considered LCA characterization models while they are known to be important drivers of biodiversity loss. Significant efforts have been made to better account for biodiversity degradation in LCA but methodological improvements and development of new indicators are still needed (Curran et al., 2016; Woods et al., 2016).

Harmonized application of the precautionary principle. Regarding the ecosystem carrying capacities, it would be worth validating the selected thresholds and uncertainty margins with panels of field experts and ensuring the consistency in threshold definition between the different pressures. Specific science-based environmental policies can be an opportunity to strengthen the adequacy of the selected thresholds and biodiversity conservation objectives. For instance, the Marine Strategy Framework Directive, whose target is to "achieve or maintain good environmental status in the marine environment" (European Parliament and Council of the European Union, 2008) may serve as a basis to propose some indicators and thresholds more specific to marine ecosystems than the ones used in this study.

Temporal dynamics. Beyond current uncertainties and subjectivity, individual ecological budgets (per person and per year) need to be considered as dynamic. Indeed, individual ecological budgets are defined as the ratio of ecosystem carrying capacity and population size, which both evolve in time. A different demographic perspective was taken for the value proposed at the endpoint level by Doka (2016), who took a future-oriented perspective and used a rough estimate of the expected peak for this century (10 billion), and the value at midpoint level where populations of 2010 where applied (6.916 billion globally and 740 million in Europe). Carrying capacities are defined here with a steady state approach and are considered independently while in fact they interfere. Approaching the carrying capacity of ecosystems for some pressures is likely to affect the ecosystems' capacity to handle other pressures. This dynamic character would need to be better taken into account in the definition of the individual ecological budgets.

Allocation process. Assigning carrying capacities between actors is intrinsically normative. Seeking consensus has been pointed out as critical to operationalize LCA-AESA (Ryberg et al., 2016). In this study, the allocation of carrying capacities to a company take a consumer perspective as it is based on the definition of the consumers' ecological budgets, considering that all human beings have the same ecological rights. Subsequently, a fraction $(\alpha)$ of the consumers' ecological budgets is assigned to the company. This allows to distinguished two incremental levels of unsustainability. Thus, the results of the case study suggest that for some pressures, not only the company exceeded its ecological budget but also exceeded the total ecological budgets of its consumers. The factor $\alpha$ reflects how carrying capacity is shared between sectors. It was defined here based on a grandfathering principle, i.e. on the current environmental interferences of the different sectors. This principle has the advantage to be quite 
transparent (although quite rough as shown in Section 4.1) but favors sectors that have the worst impacts and does not take into account the progress margins of the different sectors. Scenarios show that the agri-food sector has a substantial potential of pressures reduction notably through diet shifts (Notarnicola et al., 2017; Röös et al., 2016; WRI, 2016). Yet these improvements may still be insufficient to lower some pressures down to sustainability thresholds as defined based on a grandfathering principle. This will be probably the case for climate change as low carbon diets might still represent a substantial carbon footprint. Indeed, a vegan diet has been estimated to correspond to about $677 \mathrm{~kg} \mathrm{CO} 2 \mathrm{eq} / \mathrm{pers} / \mathrm{yr}$ (Castañé and Antón, in press) which is lower than the individual carbon budget ( $985 \mathrm{~kg} \mathrm{CO} 2$ eq/pers/yr) but still occupies about two third of it, while the fraction allocated to agriculture in this study ranged between $12 \%$ and $22 \%$. Another way to allocate carrying capacity between sectors could be based on their respective pressures reduction potential. This approach could be more dynamic and constructive but would rely on the sectoral political influence and negotiation power.

There is thus great scientific and institutional challenges to make this approach fully operational. The Intergovernmental Science-Policy Platform on Biodiversity and Ecosystem Services (IPBES) "designed to proactively develop assessments matched to policy needs, and to support capacity building across scales and topics" (Díaz et al., 2015) may play a strategic role to define ecological boundaries that reflect ecosystem-specific sensitivities, scientific knowledge and societal choices. Few companies have adopted ecological boundaries so far to frame their environmental performance and objectives (Bjørn et al., in press) although they are explicitly mentioned in CSR norms (Wolff et al., 2016b). Generalizing the use of ecological limits as references for private entities' environmental targets would increase their consistency with institutional objectives and clarify the meaning of true business sustainability (Dyllick and Muff, 2015).

\section{Conclusions}

This paper adopts a biophysically grounded view of corporate responsibilities. A method based on the LCA-AESA framework is proposed to detect whether some pressures exerted by a company and its value chain are ecologically unsustainable. The principle is to compare the environmental footprints of the entity, in terms of species loss and anthropic pressures, to its environmental budgets i.e. the carrying capacities assigned to the entity. Explicit rules are proposed to downscale global ecological boundaries at the company-level. This method allows to detect two levels of unsustainability: exceedance of the consumers' ecological budget, which means that the company exerts more impacts than what is defined as permissible to cover all the need of its consumer base, and exceedance of the fraction of the consumers' ecological budget allocated to the specific needs fulfilled by the company.

This approach was tested on the food portfolio of a mass-market retailer. The results of the case study suggest that the ecological burden is not compatible with biodiversity conservation as the agricultural step alone was found to trigger potential species loss more than ten times higher than the proposed threshold. Unsustainable pressures exerted on terrestrial and aquatic biodiversity were identified for all three types of biodiversity loss drivers under study: climate change, pollutions and habitat loss. Meat and milk were the top product contributors for most of these unsustainable pressures. Profound changes in production and consumption patterns are needed to mitigate this ecological unsustainability. The proposed strategy is to: (1) align the nutritional content of the average basket of product with nutrition guidelines, (2) substitute the 
most impacting product categories, and (3) promote environmental quality oriented products. The implementation of these orientations partly exceeds the company's capacity of influence, pleading for concerted sectoral and institutional actions.

Testing the method in partnership with a company has demonstrated the applicability of the proposed approach as well as its didactic value for decision makers as it set the grounds to discuss possible strategic orientations. This approach supports a weak to strong sustainability paradigm shift where ecological performance is assessed in reference to ecosystems' carrying capacities rather than to average sectoral performance. We recognize that much work is required to determine consistent, spatially and timely resolved ecosystems carrying capacities and that governance processes are needed to agree upon common rules to allocate carrying capacities between actors. The proposed approach open conceptual and action-oriented perspectives of collaboration between the various research and practitioners communities interested in sustainability (e.g. planetary boundaries, CSR...), striving to influence economic sectors to "make our planet great again".

\section{Acknowledgments}

The authors would like to thank Benjamin Doualle for its technical insights, Esperan Padonou for its writing assistance for the materials and methods section, Matthieu Lantrin for his work on the sensitivity analysis and Eric Pacquet for its support during the partnership.

Funding: This work was supported by AgroParistech, Ecole des Mines Saint-Etienne and the research partnership with Groupe Casino.

\section{Bibliography}

Alkemade, R., Oorschot, M. van, Miles, L., Nellemann, C., Bakkenes, M., Brink, B. ten, 2009. GLOBIO3: A Framework to Investigate Options for Reducing Global Terrestrial Biodiversity Loss. Ecosystems 12, 374-390. doi:10.1007/s10021-009-9229-5

Barnosky, A.D., Hadly, E.A., Bascompte, J., Berlow, E.L., Brown, J.H., Fortelius, M., Getz, W.M., Harte, J., Hastings, A., Marquet, P.A., Martinez, N.D., Mooers, A., Roopnarine, P., Vermeij, G., Williams, J.W., Gillespie, R., Kitzes, J., Marshall, C., Matzke, N., Mindell, D.P., Revilla, E., Smith, A.B., 2012. Approaching a state shift in Earth's biosphere. Nature 486, 52-58. doi:10.1038/nature11018

Bjørn, A., 2015. Better, but good enough? Indicators for absolute environmental sustainability in a life cycle perspective. DTU Management Engineering.

Bjørn, A., Bey, N., Georg, S., Røpke, I., Hauschild, M.Z., in press. Is Earth recognized as a finite system in corporate responsibility reporting? Journal of Cleaner Production. doi:10.1016/j.jclepro.2015.12.095

Bjørn, A., Hauschild, M.Z., 2015. Introducing carrying capacity-based normalisation in LCA: framework and development of references at midpoint level. Int J Life Cycle Assess 20, 1005-1018. doi:10.1007/s11367-015-0899-2

Borucke, M., Moore, D., Cranston, G., Gracey, K., Iha, K., Larson, J., Lazarus, E., Morales, J.C., Wackernagel, M., Galli, A., 2013. Accounting for demand and supply of the biosphere's regenerative capacity: The National Footprint Accounts' underlying methodology and framework. Ecological Indicators 24, 518-533. doi:10.1016/j.ecolind.2012.08.005 
Bouwman, A.F., Vuuren, D.P.V., Derwent, R.G., Posch, M., 2002. A Global Analysis of Acidification and Eutrophication of Terrestrial Ecosystems. Water, Air, \& Soil Pollution 141, 349-382. doi:10.1023/A:1021398008726

Butchart, S.H.M., Walpole, M., Collen, B., van Strien, A., Scharlemann, J.P.W., Almond, R.E.A., Baillie, J.E.M., Bomhard, B., Brown, C., Bruno, J., Carpenter, K.E., Carr, G.M., Chanson, J., Chenery, A.M., Csirke, J., Davidson, N.C., Dentener, F., Foster, M., Galli, A., Galloway, J.N., Genovesi, P., Gregory, R.D., Hockings, M., Kapos, V., Lamarque, J.-F., Leverington, F., Loh, J., McGeoch, M.A., McRae, L., Minasyan, A., Morcillo, M.H., Oldfield, T.E.E., Pauly, D., Quader, S., Revenga, C., Sauer, J.R., Skolnik, B., Spear, D., Stanwell-Smith, D., Stuart, S.N., Symes, A., Tierney, M., Tyrrell, T.D., Vie, J.-C., Watson, R., 2010. Global Biodiversity: Indicators of Recent Declines. Science 328, 1164-1168. doi:10.1126/science. 1187512

Castañé, S., Antón, A., in press. Assessment of the nutritional quality and environmental impact of two food diets: A Mediterranean and a vegan diet. Journal of Cleaner Production. doi:10.1016/j.jclepro.2017.04.121

Clift, R., Sim, S., King, H., Chenoweth, J.L., Christie, I., Clavreul, J., Mueller, C., Posthuma, L., Boulay, A.-M., Chaplin-Kramer, R., Chatterton, J., DeClerck, F., Druckman, A., France, C., Franco, A., Gerten, D., Goedkoop, M., Hauschild, M.Z., Huijbregts, M.A.J., Koellner, T., Lambin, E.F., Lee, J., Mair, S., Marshall, S., McLachlan, M.S., Milà i Canals, L., Mitchell, C., Price, E., Rockström, J., Suckling, J., Murphy, R., 2017. The Challenges of Applying Planetary Boundaries as a Basis for Strategic Decision-Making in Companies with Global Supply Chains. Sustainability 9, 279. doi:10.3390/su9020279

Colomb, V., Amar, S.A., Mens, C.B., Gac, A., Gaillard, G., Koch, P., Mousset, J., Salou, T., Tailleur, A., Hays, M.G., 2015a. AGRIBALYSE®, the French LCI Database for agricultural products: high quality data for producers and environmental labelling. Oilseeds and fats, Crops and Lipids 22.

Colomb, V., Colsaet, A., Basset-Mens, C., Fosse, J., Gac, A., Mevel, G., Mousset, J., Tailleur, A., Van Der Werf, H., 2015b. Analyses du Cycle de Vie en agriculture : enseignements du programme AGRIBALYSE®. Agronomie environnement \& sociétés 5, 19.

Commissariat Général au Développement Durable, 2016. L'eau et les milieux aquatiques. Chiffres clés, Repères. Commissariat Général au Développement Durable - SOeS.

COP10 CBD, 2010. Decision X/21. Business engagement. Convention pour la diversité biologique, Nagoya, Japan.

Curran, M., de Baan, L., De Schryver, A.M., van Zelm, R., Hellweg, S., Koellner, T., Sonnemann, G., Huijbregts, M.A., 2010. Toward meaningful end points of biodiversity in life cycle assessment $\dagger$. Environmental science \& technology 45, 70-79.

Curran, M., Maia de Souza, D., Antón, A., Teixeira, R.F.M., Michelsen, O., Vidal-Legaz, B., Sala, S., Milà i Canals, L., 2016. How Well Does LCA Model Land Use Impacts on Biodiversity?-A Comparison with Approaches from Ecology and Conservation. Environ. Sci. Technol. 50, 2782-2795. doi:10.1021/acs.est.5b04681

de Vries, W., Kros, J., Kroeze, C., Seitzinger, S.P., 2013. Assessing planetary and regional nitrogen boundaries related to food security and adverse environmental impacts. Current Opinion in Environmental Sustainability, Open issue 5, 392-402. doi:10.1016/j.cosust.2013.07.004

Díaz, S., Demissew, S., Carabias, J., Joly, C., Lonsdale, M., Ash, N., Larigauderie, A., Adhikari, J.R., Arico, S., Báldi, A., Bartuska, A., Baste, I.A., Bilgin, A., Brondizio, E., Chan, K.M., Figueroa, V.E., Duraiappah, A., Fischer, M., Hill, R., Koetz, T., Leadley, P., Lyver, P., Mace, G.M., Martin-Lopez, B., Okumura, M., Pacheco, D., Pascual, U., Pérez, E.S., Reyers, B., Roth, E., Saito, O., Scholes, R.J., Sharma, N., Tallis, H., Thaman, R., Watson, R., Yahara, T., Hamid, Z.A., Akosim, C., Al-Hafedh, Y., 
Allahverdiyev, R., Amankwah, E., Asah, S.T., Asfaw, Z., Bartus, G., Brooks, L.A., Caillaux, J., Dalle, G., Darnaedi, D., Driver, A., Erpul, G., Escobar-Eyzaguirre, P., Failler, P., Fouda, A.M.M., Fu, B., Gundimeda, H., Hashimoto, S., Homer, F., Lavorel, S., Lichtenstein, G., Mala, W.A., Mandivenyi, W., Matczak, P., Mbizvo, C., Mehrdadi, M., Metzger, J.P., Mikissa, J.B., Moller, H., Mooney, H.A., Mumby, P., Nagendra, H., Nesshover, C., Oteng-Yeboah, A.A., Pataki, G., Roué, M., Rubis, J., Schultz, M., Smith, P., Sumaila, R., Takeuchi, K., Thomas, S., Verma, M., Yeo-Chang, Y., Zlatanova, D., 2015. The IPBES Conceptual Framework - connecting nature and people. Current Opinion in Environmental Sustainability, Open Issue 14, 1-16. doi:10.1016/j.cosust.2014.11.002

Doka, G., 2016. Combining life cycle inventory results with planetary boundaries: The Planetary Boundary Allowance impact assessment method. Update PBA'06. Zürich.

Dyllick, T., Muff, K., 2015. Clarifying the Meaning of Sustainable Business Introducing a Typology From Business-as-Usual to True Business Sustainability. Organization Environment 1086026615575176. doi:10.1177/1086026615575176

European Commission, 2011. A renewed EU strategy 2011-14 for Corporate Social Responsibility.

European Parliament, European Council, 2008. Directive 2008/98/EC of the European Parliament and of the Council of 19 November 2008 on waste and repealing certain Directives.

Fang, K., Heijungs, R., De Snoo, G.R., 2015. Understanding the complementary linkages between environmental footprints and planetary boundaries in a footprint-boundary environmental sustainability assessment framework. Ecological Economics 114, 218 226. doi:10.1016/j.ecolecon.2015.04.008

Folke, C., Carpenter, S., Walker, B., Scheffer, M., Elmqvist, T., Gunderson, L., Holling, C.S., 2004. REGIME SHIFTS, RESILIENCE, AND BIODIVERSITY IN ECOSYSTEM MANAGEMENT. Annual Review of Ecology, Evolution, and Systematics 35, 557581. doi:10.1146/annurev.ecolsys.35.021103.105711

Galli, A., Wackernagel, M., Iha, K., Lazarus, E., 2014. Ecological Footprint: Implications for biodiversity. Biological Conservation 173, 121-132. doi:10.1016/j.biocon.2013.10.019

Garnett, T., 2011. Where are the best opportunities for reducing greenhouse gas emissions in the food system (including the food chain)? Food Policy, The challenge of global food sustainability 36, Supplement 1, S23-S32. doi:10.1016/j.foodpol.2010.10.010

Gerten, D., Hoff, H., Rockström, J., Jägermeyr, J., Kummu, M., Pastor, A.V., 2013. Towards a revised planetary boundary for consumptive freshwater use: role of environmental flow requirements. Current Opinion in Environmental Sustainability, Aquatic and marine systems 5, 551-558. doi:10.1016/j.cosust.2013.11.001

Goedkoop, M., Heijungs, R., Huijbregts, M., De Schryver, A., Struijs, J., van Zelm, R., 2013. ReCiPe 2008. A life cycle impact assessment method which comprises harmonised category indicators at the midpoint and the endpoint level. First edition (version 1.08). Report I: Characterisation.

Groupe Casino, 2016. Rapport d'activité et de performances sociétales et environnementales 2015.

Haberl, H., Kastner, T., Schaffartzik, A., Ludwiczek, N., Erb, K.-H., 2012. Global effects of national biomass production and consumption: Austria's embodied HANPP related to agricultural biomass in the year 2000. Ecological Economics, The Economics of Degrowth 84, 66-73. doi:10.1016/j.ecolecon.2012.09.014

Hoekstra, A.Y., Wiedmann, T.O., 2014. Humanity's unsustainable environmental footprint. Science 344, 1114-1117. doi:10.1126/science.1248365 
ISO, 2006. ISO 14040:2006. Environmental management - Life cycle assessment - Principles and framework. International Organization for Standardization, Geneva.

Kitzes, J., Berlow, E., Conlisk, E., Erb, K., Iha, K., Martinez, N., Newman, E.A., Plutzar, C., Smith, A.B., Harte, J., 2016. Consumption-Based Conservation Targeting: Linking Biodiversity Loss to Upstream Demand through a Global Wildlife Footprint. CONSERVATION LETTERS n/a-n/a. doi:10.1111/con4.12321

Koch, P., Salou, T., 2015. AGRIBALYSE®: Rapport Méthodologique - Version 1.2. ADEME, Anger.

Kok, M., Alkemade, R., Bakkenes, M., Boelee, E., Christensen, V., Eerdt, M. van, Esch, S. van der, Janse, J., 2014. How sectors can contribute to sustainable use and conservation of biodiversity (No. 79), CDB Technical Series. PBL Netherlands Environmental Assessment Agency, The Hague, Netherlands.

Krabbe, O., Linthorst, G., Blok, K., Crijns-Graus, W., van Vuuren, D.P., Höhne, N., Faria, P., Aden, N., Pineda, A.C., 2015. Aligning corporate greenhouse-gas emissions targets with climate goals. Nature Clim. Change 5, 1057-1060. doi:10.1038/nclimate2770

Langlois, J., Fréon, P., Steyer, J.-P., Delgenès, J.-P., Hélias, A., 2015. Sea use impact category in life cycle assessment: characterization factors for life support functions. Int $\mathbf{J}$ Life Cycle Assess 20, 970-981. doi:10.1007/s11367-015-0886-7

Lazarus, E., Lin, D., Martindill, J., Hardiman, J., Pitney, L., Galli, A., 2015. Biodiversity Loss and the Ecological Footprint of Trade. Diversity 7, 170-191. doi:10.3390/d7020170

Leip, A., Billen, G., Garnier, J., Grizzetti, B., Lassaletta, L., Reis, S., David Simpson, Sutton, M.A., Vries, W. de, Weiss, F., Westhoek, H., 2015. Impacts of European livestock production: nitrogen, sulphur, phosphorus and greenhouse gas emissions, land-use, water eutrophication and biodiversity. Environ. Res. Lett. 10, 115004. doi:10.1088/1748-9326/10/11/115004

Lenzen, M., Moran, D., Kanemoto, K., Foran, B., Lobefaro, L., Geschke, A., 2012. International trade drives biodiversity threats in developing nations. Nature 486, 109 112. doi:10.1038/nature 11145

Mace, G.M., Reyers, B., Alkemade, R., Biggs, R., Chapin III, F.S., Cornell, S.E., Díaz, S., Jennings, S., Leadley, P., Mumby, P.J., Purvis, A., Scholes, R.J., Seddon, A.W.R., Solan, M., Steffen, W., Woodward, G., 2014. Approaches to defining a planetary boundary for biodiversity. Global Environmental Change 28, 289-297. doi:10.1016/j.gloenvcha.2014.07.009

Machovina, B., Feeley, K.J., Ripple, W.J., 2015. Biodiversity conservation: The key is reducing meat consumption. Science of The Total Environment 536, 419-431. doi:10.1016/j.scitotenv.2015.07.022

Millennium Ecosystem Assessment, 2005. Ecosystems and Human Well-Being: Current State and Trends, Island Press. ed. Washington, D.C., USA.

Moran, D., Kanemoto, K., 2017. Identifying species threat hotspots from global supply chains. Nature Ecology \& Evolution 1, 0023. doi:10.1038/s41559-016-0023

Moran, D., Petersone, M., Verones, F., 2016. On the suitability of input-output analysis for calculating product-specific biodiversity footprints. Ecological Indicators 60, 192-201. doi:10.1016/j.ecolind.2015.06.015

Newbold, T., Hudson, L.N., Hill, S.L., Contu, S., Lysenko, I., Senior, R.A., Börger, L., Bennett, D.J., Choimes, A., Collen, B., others, 2015. Global effects of land use on local terrestrial biodiversity. Nature 520, 45-50.

Noss, R.F., Dobson, A.P., Baldwin, R., Beier, P., Davis, C.R., Dellasala, D.A., Francis, J., Locke, H., Nowak, K., Lopez, R., Reining, C., Trombulak, S.C., Tabor, G., 2012. Bolder Thinking for Conservation. Conservation Biology 26, 1-4. doi:10.1111/j.15231739.2011.01738.x 
Notarnicola, B., Tassielli, G., Renzulli, P.A., Castellani, V., Sala, S., 2017. Environmental impacts of food consumption in Europe. Journal of Cleaner Production, Towards ecoefficient agriculture and food systems: selected papers addressing the global challenges for food systems, including those presented at the Conference "LCA for Feeding the planet and energy for life" (6-8 October 2015, Stresa \& Milan Expo, Italy) 140, Part 2, 753-765. doi:10.1016/j.jclepro.2016.06.080

Phalan, B., Hayes, G., Brooks, S., Marsh, D., Howard, P., Costelloe, B., Vira, B., Kowalska, A., Whitaker, S., 2017. Avoiding impacts on biodiversity through strengthening the first stage of the mitigation hierarchy. Oryx 1-9. doi:10.1017/S0030605316001034

Reid, R.S., Bedelian, C., Said, M.Y., Kruska, R.L., Mauricio, R.M., Castel, V., Olson, J., Thornton, P.K., 2010. Global livestock impacts on biodiversity, in: Livestock in a Changing Landscape (Volume 1): Drivers Consequences, and Responses. Island Press, Washington D.C, pp. 111-137.

Repar, N., Jan, P., Dux, D., Nemecek, T., Doluschitz, R., 2017. Implementing farm-level environmental sustainability in environmental performance indicators: A combined global-local approach. Journal of Cleaner Production, Towards eco-efficient agriculture and food systems: selected papers addressing the global challenges for food systems, including those presented at the Conference "LCA for Feeding the planet and energy for life" (6-8 October 2015, Stresa \& Milan Expo, Italy) 140, Part 2, 692-704. doi:10.1016/j.jclepro.2016.07.022

Robinson, S.A., Erickson, D.J., 2015. Not just about sunburn - the ozone hole's profound effect on climate has significant implications for Southern Hemisphere ecosystems. Glob Change Biol 21, 515-527. doi:10.1111/gcb.12739

Rockström, J., Steffen, W., Noone, K., Persson, ̊., Chapin, F.S., Lambin, E., Lenton, T.M., Scheffer, M., Folke, C., Schellnhuber, H.J., Nykvist, B., Wit, D., A, C., Hughes, T., van der Leeuw, S., Rodhe, H., Sörlin, S., Snyder, P.K., Costanza, R., Svedin, U., Falkenmark, M., Karlberg, L., Corell, R.W., Fabry, V.J., Hansen, J., Walker, B., Liverman, D., Richardson, K., Crutzen, P., Foley, J., 2009. Planetary Boundaries: Exploring the Safe Operating Space for Humanity. Ecology \& society 14, 32.

Röös, E., Patel, M., Spångberg, J., Carlsson, G., Rydhmer, L., 2016. Limiting livestock production to pasture and by-products in a search for sustainable diets. Food Policy 58, 1-13. doi:10.1016/j.foodpol.2015.10.008

Rothman, D.S., 1998. Environmental Kuznets curves - real progress or passing the buck?: A case for consumption-based approaches. Ecol.Econ. 25, 177-194. doi:10.1016/S09218009(97)00179-1

Ryberg, M.W., Owsianiak, M., Richardson, K., Hauschild, M.Z., 2016. Challenges in implementing a Planetary Boundaries based Life-Cycle Impact Assessment methodology. Journal of Cleaner Production 139, 450-459. doi:10.1016/j.jclepro.2016.08.074

Saad, R., Koellner, T., Margni, M., 2013. Land use impacts on freshwater regulation, erosion regulation, and water purification: a spatial approach for a global scale level. The International Journal of Life Cycle Assessment 18, 1253-1264.

Sala, S., Benini, L., Crenna, E., Secchi, M., 2016. Global environmental impacts and planetary boundaries in LCA. Data sources and methodological choices for the calculation of global and consumption-based normalisation factors. JRC.

Sandin, G., Peters, G.M., Svanström, M., 2015. Using the planetary boundaries framework for setting impact-reduction targets in LCA contexts. Int J Life Cycle Assess 20, 16841700. doi:10.1007/s11367-015-0984-6 
Sandström, V., Kauppi, P.E., Scherer, L., Kastner, T., 2017. Linking country level food supply to global land and water use and biodiversity impacts: The case of Finland. Science of The Total Environment 575, 33-40. doi:10.1016/j.scitotenv.2016.10.002

SCBD, 2010. Global Biodiversity Outlook 3. Secretariat of the Convention on Biological Diversity (SCBD), Montreal, Canada.

Science-based Targets initiative, 2017. Science-based Target Setting Manual. Version 3.0. CDP, UN GLobal Compact, WRI, WWF.

Steffen, W., Richardson, K., Rockström, J., Cornell, S.E., Fetzer, I., Bennett, E.M., Biggs, R., Carpenter, S.R., Vries, W. de, Wit, C.A. de, Folke, C., Gerten, D., Heinke, J., Mace, G.M., Persson, L.M., Ramanathan, V., Reyers, B., Sörlin, S., 2015. Planetary boundaries: Guiding human development on a changing planet. Science 347, 1259855. doi:10.1126/science. 1259855

Steinfeld, H., Gerber, P., Wassenaar, T., Castel, V., Rosales, M., de Haan, C., 2006. Livestock's long shadow. FAO, Rome.

Tilman, D., Clark, M., 2014. Global diets link environmental sustainability and human health. Nature 515, 518-522. doi:10.1038/nature13959

Tittensor, D.P., Walpole, M., Hill, S.L.L., Boyce, D.G., Britten, G.L., Burgess, N.D., Butchart, S.H.M., Leadley, P.W., Regan, E.C., Alkemade, R., Baumung, R., Bellard, C., Bouwman, L., Bowles-Newark, N.J., Chenery, A.M., Cheung, W.W.L., Christensen, V., Cooper, H.D., Crowther, A.R., Dixon, M.J.R., Galli, A., Gaveau, V., Gregory, R.D., Gutierrez, N.L., Hirsch, T.L., Höft, R., Januchowski-Hartley, S.R., Karmann, M., Krug, C.B., Leverington, F.J., Loh, J., Lojenga, R.K., Malsch, K., Marques, A., Morgan, D.H.W., Mumby, P.J., Newbold, T., Noonan-Mooney, K., Pagad, S.N., Parks, B.C., Pereira, H.M., Robertson, T., Rondinini, C., Santini, L., Scharlemann, J.P.W., Schindler, S., Sumaila, U.R., Teh, L.S.L., Kolck, J. van, Visconti, P., Ye, Y., 2014. A mid-term analysis of progress toward international biodiversity targets. Science 346, 241-244. doi:10.1126/science. 1257484

Tukker, A., Huppes, G., Guinée, J., Heijungs, R., Koning, A. de, van oers, L., Suh, S., Geerken, T., 2006. Environmental Impact of Products (EIPRO) - Analysis of the life cycle environmental impacts related to the final consumption of the EU-25. JRC.

Urban, M.C., 2015. Accelerating extinction risk from climate change. Science 348, 571-573. doi:10.1126/science.aaa4984

Verheijen, F.G.A., Jones, R.J.A., Rickson, R.J., Smith, C.J., 2009. Tolerable versus actual soil erosion rates in Europe. Earth-Science Reviews 94, 23-38. doi:10.1016/j.earscirev.2009.02.003

Verones, F., Moran, D., Stadler, K., Kanemoto, K., Wood, R., 2017. Resource footprints and their ecosystem consequences. Sci Rep 7. doi:10.1038/srep40743

Wilting, H.C., Schipper, A.M., Bakkenes, M., Meijer, J.R., Huijbregts, M.A.J., 2017. Quantifying Biodiversity Losses Due to Human Consumption: A Global-Scale Footprint Analysis. Environ. Sci. Technol. 51, 3298-3306. doi:10.1021/acs.est.6b05296

Wilting, H.C., van Oorschot, M.M.P., 2017. Quantifying biodiversity footprints of Dutch economic sectors: A global supply-chain analysis. Journal of Cleaner Production 156, 194-202. doi:10.1016/j.jclepro.2017.04.066

Wolff, A., Gondran, N., Brodhag, C., 2016a. A proposal to assess ecological sustainability of the pressures exerted by livestock on biodiversity. Presented at the 22nd SETAC Europe LCA Case Study Symposium, Montpellier, France.

Wolff, A., Gondran, N., Brodhag, C., 2016b. Les défis de l'intégration de la biodiversité dans la stratégie RSE, in: RIODD 2016. Saint-Étienne, France. 
Woods, J.S., Veltman, K., Huijbregts, M.A.J., Verones, F., Hertwich, E.G., 2016. Towards a meaningful assessment of marine ecological impacts in life cycle assessment (LCA). Environment International 89-90, 48-61. doi:10.1016/j.envint.2015.12.033

WRI, 2016. Shifting Diets for a Sustainable Food Future (Working Paper). World Resource Institute. 